\title{
P2X7 receptor-pannexin 1 interaction mediates extracellular alpha-synuclein-induced ATP release in neuroblastoma SH-SY5Y cells
}

\author{
Anna Wilkaniec $^{1}$ (D) Magdalena Gąssowska ${ }^{1}$ - Grzegorz A. Czapski ${ }^{1}$. \\ Magdalena Cieślik $^{1}$ • Grzegorz Sulkowski ${ }^{2}$ - Agata Adamczyk ${ }^{1}$
}

Received: 7 February 2017 / Accepted: 30 April 2017 /Published online: 17 May 2017

(C) The Author(s) 2017. This article is an open access publication

\begin{abstract}
Abnormalities of alpha-synuclein (ASN), the main component of protein deposits (Lewy bodies), were observed in Parkinson's disease (PD), dementia with Lewy bodies, Alzheimer's disease, and other neurodegenerative disorders. These alterations include increase in the levels of soluble ASN oligomers in the extracellular space. Numerous works have identified several mechanisms of their toxicity, including stimulation of the microglial $\mathrm{P} 2 \mathrm{X} 7$ receptor leading to oxidative stress. While the significant role of purinergic signaling - particularly, P2 family receptors - in neurodegenerative disorders is well known, the interaction of extracellular soluble ASN with neuronal purinergic receptors is yet to be studied. Therefore, in this study, we have investigated the effect of ASN on P2 purinergic receptors and ATP-dependent signaling. We used neuroblastoma SH-SY5Y cell line and rat synaptoneurosomes treated with exogenous soluble ASN. The experiments were performed using spectrofluorometric, radiochemical, and immunochemical methods. We found the following: (i) ASN-induced intracellular free calcium mobilization in neuronal cells and nerve endings depends on the activation of purinergic $\mathrm{P} 2 \mathrm{X} 7$ receptors; (ii) activation of $\mathrm{P} 2 \mathrm{X} 7$ receptors leads to pannexin 1 recruitment to form an active complex responsible for ATP release; and (iii) ASN greatly decreases the activity of extracellular ecto-ATPase
\end{abstract}

Anna Wilkaniec

awilkaniec@imdik.pan.pl

1 Department of Cellular Signalling, Mossakowski Medical Research Centre, Polish Academy of Sciences, Pawińskiego 5 St., 02-106 Warsaw, Poland

2 Department of Neurochemistry, Laboratory of Pathoneurochemistry, Mossakowski Medical Research Centre, Polish Academy of Sciences, Pawińskiego 5 St., 02-106 Warsaw, Poland responsible for ATP degradation. Thus, it is concluded that purinergic receptors might be putative pharmacological targets in the molecular mechanism of extracellular ASN toxicity. Interference with $\mathrm{P} 2 \mathrm{X} 7$ signaling seems to be a promising strategy for the prevention or therapy of PD and other neurodegenerative disorders.

Keywords Alpha-synuclein · Purinergic P2 receptors · P2X7 receptor $\cdot$ Extracellular ATP $\cdot$ Ecto-ATPase $\cdot$ Pannexin 1

\section{Introduction}

Both oligomerization and accumulation of alpha-synuclein (ASN) are the key molecular processes involved in the pathophysiology of neurodegenerative diseases such as Parkinson's disease (PD), Alzheimer's disease (AD), and other synucleinopathies [1]. Alterations of ASN expression and impairment of its degradation can lead to the formation of intracellular deposits of this protein, called Lewy bodies (LB) [2]. Previous data have indicated that the key process responsible for the propagation and expansion of neurodegeneration in the brain is the release of ASN to extracellular space $[1,3]$. According to these, ASN released to extracellular compartment (by exocytosis or as an effect of neurodegeneration) easily changes the structure to $\beta$-sheet and acts outside the cell or penetrates the neuronal or glial cells in a manner dependent on the concentration and aggregation stage [4]. When ASN reaches the increased concentration inside the neuron, oligomerization that leads to cell death starts. The molecular mechanisms of extracellular ASN-mediated toxicity include $\mathrm{Ca}^{2+}$ deregulation, enhancement of the reactive oxygen and nitrogen species production, mitochondria dysfunction, deregulation of dopaminergic and glutamatergic neurotransmission, and activation of brain neuroinflammation [5-12]. 
In parallel to the ASN-related hypothesis for neurodegenerative disorders, extracellular ATP release and purinergic neurotransmission have been recently shown to participate in the pathogenesis and progression of nervous system diseases [13, 14]. A significant amount of ATP can be released from many cell types in response to mechanical stress, inflammation, oxygen deprivation, or apoptotic stimuli through the opening of pannexin 1 channels [15-18]. In addition, ATP could be stored in special secretory vesicles and released by exocytosis from nerve terminals [19]. The secreted ATP is later sequentially degraded to ADP, AMP, and adenosine by plasma membrane nucleotidases [20,21]. Activity of ATP and other extracellular nucleotides (ADP, UTP, and UDP) is mediated by the membrane $\mathrm{P} 2$ receptors, which based on pharmacology [22] and molecular cloning [23] can be subdivided into two types-ionotropic (P2X) and metabotropic (P2Y) receptors. Most studies of the extracellular actions of ATP connected with the short-term neurotransmission and neuromodulation events are related to $\mathrm{P} 2 \mathrm{X}$ receptormediated $\mathrm{Ca}^{2+}$ permeability and membrane depolarization. However, by acting on $\mathrm{P} 2$ receptors, ATP can also have potent long-term (trophic) role by regulating two important second messengers: cytoplasmic $\mathrm{Ca}^{2+}$ and cyclic adenosine monophosphate (cAMP) [24, 25], thus providing a direct link between functional activity in neural circuits and cellular growth and differentiation. Depending on the cell type, expression of selective receptor subtypes, ecto-enzymes activity, and functional state of the cells, purinergic signaling may activate various signaling pathways from mitogenesis to apoptosis [24]. In pathological conditions, like cerebral trauma, ischemia, or neurodegeneration, not only the extracellular release of nucleotides may be significantly elevated, but also the expression of $\mathrm{P} 2$ receptors and the activity of extracellular ecto-nucleotidases may undergo certain changes, resulting in CNS dysfunctions [26]. Currently, it is being emphasized that purinergic signaling-dependent induction of neuroinflammation plays an important role in pathophysiology and progression of neurodegeneration [27-29]. Extracellular nucleotides regulate inflammatory signaling by inducing the microglia and astrocytes activation $[30,31]$, cytokines release (IL-1 $\beta$, IL-6, TNF- $\alpha$ ), and phagocytosis [32]. In the course of neurodegeneration, the change in $\mathrm{P} 2$ receptor expression and activity in neuronal cells was also observed. The P2X7 receptormediated $\mathrm{Ca}^{2+}$ entry and mitochondrial dysfunction were previously observed to play important role in the ATP-induced neuronal death [33]. Release of ATP from disrupted cells might cause cell death in neighboring cells, which express P2X7 receptors, leading to a necrotic volume increase [34]. Based on these data, deregulation of purinergic signaling may be an important factor related to ASN-induced pathology within CNS. Jiang et al. [12] showed that stimulation of the microglial P2X7 receptor by extracellular ASN resulted in increased oxidative stress. Although this interaction is relevant, it is yet to be studied within the neuronal cells. Therefore, the aim of this project was to investigate whether ASN can also induce changes in the ATP-mediated signaling in neuronal cells.

\section{Materials and methods}

\section{Materials}

ASN was obtained from rPeptide (Bogart, GA, USA). Antagonists of purinergic receptors, such as 3-[1-[[(3'-nitro[1,1'-biphenyl]-4-yl)oxy]methyl]-3-(4-pyridinyl)propyl]2,4-thiazolidinedione (AZ 11645373), 5-(3-bromophenyl)-1,3dihydro-2H-benzofuro[3,2-e]-1,4-diazepin-2-one (5-BDBD), and $\left(1 R^{*}, 2 S^{*}\right)-4$-[2-chloro-6-(methylamino)-9H-purin-9-yl]2-(phosphonooxy)bicyclo[3.1.0]hexane-1-methanol dihydrogen phosphate ester diammonium salt (MRS 2279) were obtained from Tocris Bioscience (Bristol, UK). Neuroblastoma SH-SY5Y cell line and cell culture reagents, such as minimum essential medium eagle (MEM), Ham's F12 medium, Hank's balanced salt solution (HBSS), nonessential amino acid solution, fetal bovine serum (FBS), penicillin, streptomycin, and L-glutamine, as well as antibodies anti-P2X7R, anti-P2Y1, anti-glyceraldehyde 3-phosphate dehydrogenase (GAPDH), anti-rabbit IgG, and other reagents such as ARL 67156, ATP disodium salt, carbenoxolone (CBX), pyridoxal-5'-phosphate-6-azo-phenyl-2,4-disulfonate (PPADS), TRI-reagent, DNase I, dimethyl sulfoxide (DMSO), and bovine serum albumin (BSA) were purchased from SigmaAldrich (St. Louis, MO, USA). Reagents for reverse transcription (high capacity RNA-to-complementary DNA (cDNA) Master Mix), PCR (Gene Expression Master Mix), TaqMan Gene expression assays, Fluo-4 AM, and Molecular Probes ${ }^{\circledR}$ ATP determination kit were obtained from Thermo Fisher Scientific (Waltham, MA, USA). Clarity ${ }^{\mathrm{TM}}$ Western ECL Substrate was from Bio-Rad Laboratories (Hercules, CA, USA). Cell lysis buffer was obtained from Cell Signaling Technology (Beverly, MA, USA). All other reagents were purchased from POCh (Gliwice, Poland).

\section{Preparation of soluble ASN}

Human ASN was dissolved in phosphate-buffered saline (PBS) (pH 7.4) at a concentration of $100 \mu \mathrm{M}$ and immediately used for experiments as soluble ASN in the form of mixture of monomers and oligomers [9].

\section{Cell culture}

The studies were carried out using human neuroblastoma SHSY5Y cell line, which is known to be able to both proliferate 
and differentiate in culture. SH-SY5Y cells were cultured in F12/MEM medium supplemented with $15 \%$ heat-inactivated FBS, $1 \%$ non-essential amino acids, 50 units $/ \mathrm{ml}$ penicillin, and $50 \mu \mathrm{g} / \mathrm{ml}$ streptomycin as well as L-glutamine at $37{ }^{\circ} \mathrm{C}$ in a humidified incubator containing $5 \% \mathrm{CO}_{2}$.

\section{Cellular treatment}

SH-SY5Y cells were plated in 60 - and $35-\mathrm{mm}$ culture dishes or 96-well plates, and the growth medium was changed into a low-serum medium (MEM/F12 supplemented with $2 \%$ FBS, $1 \%$ penicillin/streptomycin, and $1 \%$ L-glutamine). HBSS or other media appropriate for the particular procedure were also used. Then, the cells were treated with exogenous ASN $(10 \mu \mathrm{M})$, specific agonist, and antagonists of purinergic receptors: ATP ( $5 \mathrm{mM}, \mathrm{pH} 7.3-7.5)$, PPADS $(100 \mu \mathrm{M}$, dissolved in $\left.\mathrm{H}_{2} \mathrm{O}\right)$, MRS $2279\left(10 \mu \mathrm{M}\right.$, dissolved in $\left.\mathrm{H}_{2} \mathrm{O}\right)$, 5-BDBD $(100 \mu \mathrm{M}$, dissolved in DMSO), and AZ $11645373(10 \mu \mathrm{M}$, dissolved in DMSO), as well as antagonist of pannexin channels- CBX $\left(10 \mu \mathrm{M}\right.$, dissolved in $\left.\mathrm{H}_{2} \mathrm{O}\right)$ or thapsigargin (THAPS, $10 \mathrm{nM}$, dissolved in DMSO) - inhibitor of the sarco/endoplasmic reticulum $\mathrm{Ca}^{2+}$ ATPase (SERCA) for appropriate time points. Appropriate solvent was added to respective controls.

\section{Animals}

All the experiments were carried out on male Wistar rats, 4 months old, supplied from Animal House of Medical Research Center, Polish Academy of Sciences (Warsaw, Poland), which operates breeding of small rodents in SPF standard. The animals were maintained under controlled conditions of temperature and humidity with 12-h light/dark cycle. All efforts were made to minimize animal suffering and to reduce the number of animals used. All manipulations were performed gently and quickly to avoid stress-induced alterations.

\section{Preparation of synaptoneurosomes-enriched fraction}

Male Wistar rats were decapitated, brains were isolated, and the cerebral cortex, including the hippocampus, was manually dissected with a chilled razor blade on an ice-chilled Petri dish. Synaptoneurosomes were prepared according to Adamczyk and Strosznajder [10] and Strosznajder and Samochocki [35]. Briefly, brain slices were homogenized by hand (five strokes) in $7 \mathrm{ml} \mathrm{Krebs-Henseleit} \mathrm{buffer,} \mathrm{pH} 7.4$ $\left[120 \mathrm{mM} \mathrm{NaCl}, 5 \mathrm{mM} \mathrm{KCl}, 1.2 \mathrm{mM} \mathrm{MgSO}_{4}, 1.2 \mathrm{mM}\right.$ $\mathrm{KH}_{2} \mathrm{PO}_{4}, 25 \mathrm{mM} \mathrm{NaHCO}$, and $10 \mathrm{mM}$ glucose equilibrated with $\left.\mathrm{O}_{2} / \mathrm{CO}_{2}(95 / 5)\right]$, using a Dounce-type glass homogenizer. The homogenate was diluted with $28 \mathrm{ml} \mathrm{Krebs-Henseleit}$ buffer and centrifuged at $1100 \times g$ for $15 \mathrm{~min}$. The supernatant was decanted, and the pellet was resuspended in $5 \mathrm{ml}$ of the
HBSS solution with $5 \mathrm{mM}, N$-(2-hydroxyethyl)piperazine$N^{\prime}$-(2-ethanesulfonic acid) (HEPES) buffer of $\mathrm{pH}$ 7.4. The particulate preparations from rat cerebral cortex were examined by electron microscopy as described previously [35]. The preparation contained erythrocytes, axonal fragments, dendritic processes, cell nuclei, myelin fragments, and free mitochondria, but the majority of the content were presynaptic sacs (synaptosomes) attached to membrane-bound postsynaptic sacs (neurosomes) (Fig. 1a, b). Further, Western blot analysis of the obtained fraction showed that this preparation is more characterized with the enrichment of pre- and postsynaptic proteins: synaptophysin and postsynaptic density protein 95 (PSD95), compared to homogenate from brain cortex (Fig. 1c). For further experiments, the obtained preparation rich with synaptoneurosomes was preincubated at $37^{\circ} \mathrm{C}$ for $30 \mathrm{~min}$.

\section{Fluorometric measurements of changes in $\left[\mathrm{Ca}^{2+}\right]_{i}$}

Changes in intracellular $\mathrm{Ca}^{2+}\left(\left[\mathrm{Ca}^{2+}\right]_{i}\right)$ concentration in SHSY5Y cells were monitored using the fluorescent calciumsensitive probe Fluo-4. Its acetoxymethyl ester derivative, Fluo-4 AM, easily penetrates plasma membranes, and inside the cells, it is cleaved by esterases to Fluo-4, which becomes highly fluorescent after binding with $\mathrm{Ca}^{2+}$. The procedure is essential, as has been described previously by Wilkaniec et al. [36]. SH-SY5Y cells were seeded onto collagen-coated 96-well dark plates at the density of $1.4 \times 10^{5}$ cells $/ \mathrm{ml}$. After $24 \mathrm{~h}$, the cells were loaded with $10 \mu \mathrm{M}$ Fluo-4 AM supplemented with $0.02 \%$ Pluronic $® \mathrm{~F}-68$ for $60 \mathrm{~min}$ at $37^{\circ} \mathrm{C}$ in a standard HBSS. The cells were washed three times with HBSS and, to ensure complete AM ester hydrolysis, kept for $30 \mathrm{~min}$ at $37^{\circ} \mathrm{C}$ in the dark. After a second washing, the fluorescence was measured using a microplate reader FLUOstar Omega (Ortenberg, Germany) set at $485 \mathrm{~nm}$ excitation and $538 \mathrm{~nm}$ emission wavelengths. After determining the baseline fluorescence of the cells incubated in HBSS, the changes in fluorescence after the addition of the test compounds were recorded every $15 \mathrm{~s}$ for $5 \mathrm{~min}$. This 5-min treatment did not have any significant impact on cell viability. The results of fluorescence measurements are presented as percent changes in fluorescence intensity relative to the basal level versus duration of measurement $(\% \mathrm{~F} / \mathrm{F} 0)$. To quantify the change in the dynamics of the $\mathrm{Ca}^{2+}$ responses, the area under the curve (AUC) was calculated as a measure for the increase in intracellular $\mathrm{Ca}^{2+}[37]$.

\section{Assay of radioactive ${ }^{[45]} \mathrm{Ca}^{2+}$ influx in neuroblastoma cell line}

The procedure was performed as described previously [38]. The SH-SY5Y cells $\left(4 \times 10^{6}\right.$ cells/well) were preincubated for $5 \mathrm{~min}$ in the Locke 5 medium containing $5 \mathrm{mM}$ HEPES (pH 7.4), followed by a 5-min incubation with appropriate agents. Then, ${ }^{[45]} \mathrm{CaCl}_{2}(1 \mu \mathrm{Ci} /$ well $)$ was added for $10 \mathrm{~min}$. 
Fig. 1 Electron micrographs of representative sample of synaptoneurosomes-enriched fraction isolated from mouse cerebral cortex and hippocampus. a A typical large field view of synaptoneurosomes $(8.000 \times)$.

Mitochondria $(\mathrm{m})$ are also present. b Higher magnification of the complete synaptoneurosome where the presynaptic terminal displays vesicles and a postsynaptic membrane contains PSDs $(20.000 \times)$. Synaptosome $(S)$, presynaptic vesicles $(p v)$, neurosome $(N)$, and densely stained membranes that characterize PSDs (PSD) are shown. c Total protein $(40 \mu \mathrm{g})$ from rat synaptoneurosomesenriched fraction (syn.) or brain tissue homogenates (hom.) was analyzed by Western blot. The pre- and postsynaptic protein markers evaluated include synaptophysin and postsynaptic density protein 95 (PSD95). $G A P D H$ served as a loading control
A

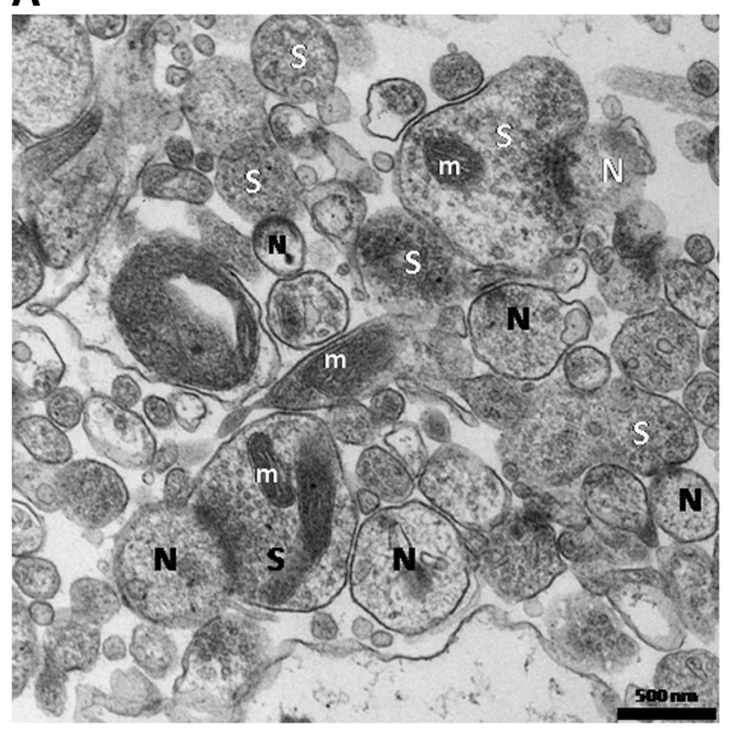

B
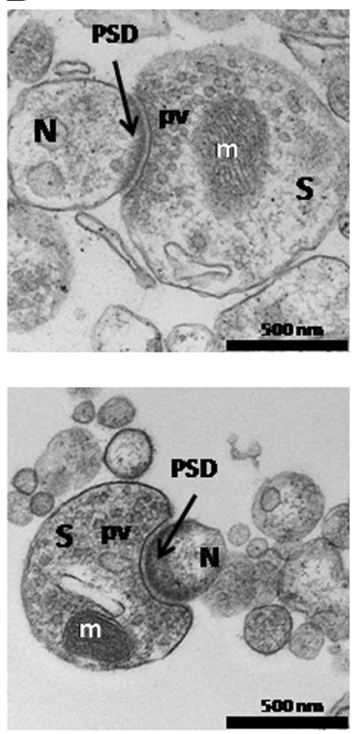

C

syn. hom.

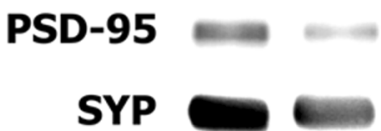

GAPDH

The incubation was terminated by washing with ice-cold calcium-free medium containing $2 \mathrm{mM}$ ethylene glycolbis( $\beta$-aminoethyl ether)- $N, N, N^{\prime}, N^{\prime}$-tetra acetic acid (EGTA), and the cells were dissolved in $0.5 \mathrm{M} \mathrm{NaOH}$ for $30 \mathrm{~min}$ at $4{ }^{\circ} \mathrm{C}$. The content of radioactive ${ }^{[45]} \mathrm{Ca}^{2+}$ in the cultures was measured by liquid scintillation spectroscopy using a Wallac 1409 counter (Wallac, Turku, Finland).

\section{Assay of radioactive ${ }^{[45]} \mathrm{Ca}^{2+}$ influx in synaptoneurosome-enriched fraction}

The radiochemical measurement of ${ }^{[45]} \mathrm{Ca}^{2+}$ influx was performed according to Adamczyk, Strosznajder [10] with slight modifications. Briefly, $0.7 \mathrm{mg}$ of the synaptoneurosomes preparation in $0.1 \mathrm{ml} \mathrm{HBSS}$ containing $1.2 \mathrm{mM} \mathrm{CaCl}_{2}$ was preincubated at $37{ }^{\circ} \mathrm{C}$ for 30 min either alone or with ASN $(10 \mu \mathrm{M})$ or ATP $(5 \mathrm{mM})$. In selected experiments, synaptoneurosomes were first preincubated with PPADS $(100 \mu \mathrm{M})$ or AZ $11645373(10 \mu \mathrm{M})$ for $5 \mathrm{~min}$ before the addition of ASN or ATP. The reaction was started by adding $0.1 \mu \mathrm{Ci}{ }^{[45]} \mathrm{CaCl}_{2}$. After $30 \mathrm{~s}$ of incubation at $37^{\circ} \mathrm{C}$, the samples were diluted with $5 \mathrm{ml}$ ice-cold assay buffer with $5 \mathrm{mM}$ EGTA, immediately filtered through Whatman GF/C filters under vacuum pressure, and washed three times in $5 \mathrm{ml}$ assay buffer. Filters were placed in $8 \mathrm{ml}$ Bray's scintillation fluid, and intrasynaptoneurosomal ${ }^{[45]} \mathrm{Ca}^{2+}$ was measured in a liquid scintillation counter LKB Wallac 1409 (Finland).

\section{RT-PCR}

The total RNA isolation was performed according to the procedure developed by Chomczyński, using TRI Reagent® (cat. T9424) from Sigma-Aldrich, following the manufacturer's protocol. Digestion of DNA contamination was performed using DNase I according to the manufacturer's protocol (Sigma-Aldrich, St. Louis, MO, USA). RNA quantity and quality were controlled by spectrophotometric analysis and gel electrophoresis. A reverse transcription was performed by using the high capacity cDNA reverse transcription kit according to the manufacturer's protocol (Applied Biosystems, Foster City, CA, USA). Quantitative real-time PCR was performed with TaqMan Universal PCR Master Mix (Applied Biosystems, Foster City, CA, USA) and detected by a Real-Time PCR System on an ABI PRISM 7500 apparatus (Thermo Fisher Scientific, Waltham, MA, USA) using the commercially available TaqMan ${ }^{\circledR}$ Gene Expression Assays: Hs00602442 m1 (P2rx4, amplicon length 91), Hs00175721_m1 (P2rx7, amplicon length 89), Hs00704965_s1 (P2ry1, amplicon length 73), Hs04176264_s1 (P2ry2, amplicon length 82), and Hs01060665 g1 (Actb, amplicon length 63). After 2-min incubation at $50{ }^{\circ} \mathrm{C}$, required for optimal AmpErase UNG activity followed by activation of AmpliTaq Gold Enzyme (10 min incubation at $95^{\circ} \mathrm{C}$ ), a standard two-step PCR amplification was performed, with a melting step at $95^{\circ} \mathrm{C}$ for $15 \mathrm{~s}$ 
and annealing and elongation at $60^{\circ} \mathrm{C}$ for $1 \mathrm{~min}$, for 40 cycles. $A c t b$ was used in the analysis as a reference gene. The relative levels of target messenger RNA (mRNA), normalized to an endogenous reference and relative to a calibrator, were calculated by $2^{-\Delta \Delta \mathrm{CT}}$ formula.

\section{Western blot analysis}

The cells were washed three times with ice-cold PBS and lyzed in cell lysis buffer $(1 \times)$. Protein levels were determined using the Lowry method, and then the samples were mixed with Laemmli buffer and denatured at $95^{\circ} \mathrm{C}$ for $5 \mathrm{~min}$. After standard 10\% SDS-PAGE separation, proteins were transferred onto PVDF membranes at $100 \mathrm{~V}$. Next, the membranes were washed for $5 \mathrm{~min}$ in $100 \mathrm{mM}$ Tris-buffered saline with $0.1 \%$ Tween 20 (TBST) and $140 \mathrm{mM} \mathrm{NaCl}$ at $\mathrm{pH} 7.6$, and the non-specific bindings were blocked for $60 \mathrm{~min}$ at room temperature (RT) with 5\% BSA solution in TBST or with 5\% nonfat milk solution in TBST. Further, membranes were washed three times for $5 \mathrm{~min}$ in TBST and incubated with the following primary antibody: rabbit monoclonal anti-P2X7R (SigmaAldrich, cat. P8232; $1: 200$ ) [39] in a 5\% BSA solution in TBST, overnight at $4{ }^{\circ} \mathrm{C}$ and rabbit monoclonal anti-P2Y1 (Sigma-Aldrich, cat. P6487; 1 : 200) [40] in TBST overnight at $4{ }^{\circ} \mathrm{C}$. Then, the membranes were washed three times ( $5 \mathrm{~min}$ ) in TBST and incubated for $60 \mathrm{~min}$ at RT with secondary antibody (anti-rabbit or anti-mouse $\operatorname{IgG})(1: 4000)$ in a $5 \%$ non-fat milk/TBST. Antibodies were detected using chemiluminescent Clarity Western ECL Substrate (Bio-Rad Laboratories, Hercules, CA, USA) under standard conditions. After stripping, the immunolabeling of GAPDH was performed as a loading control.

\section{Measurement of extracellular pools of ATP}

Measurement of ATP level was performed according to the method previously described by Karczewska et al. [41]. For the determination of extracellular ATP concentration, SHSY5Y cells were seeded onto collagen-coated 24-well plates at the density of $1.5 \times 10^{5}$ cells $/ \mathrm{ml}$. After $24 \mathrm{~h}$, the culture medium was carefully changed into $300 \mu$ of HBSS with $5 \mathrm{mM}$ HEPES ( $\mathrm{pH}$ 7.4) and cells were preincubated for $60 \mathrm{~min}$ at $37{ }^{\circ} \mathrm{C}$. Then, the selected agents were carefully added to the cells for $1 \mathrm{~min}$. Later, $100 \mu \mathrm{l}$ of incubation media was collected into Eppendorf tubes placed at $99{ }^{\circ} \mathrm{C}$ for $2 \mathrm{~min}$ and centrifuged $\left(4^{\circ} \mathrm{C}, 800 \times g, 10 \mathrm{~min}\right)$, in order to inactivate the enzymatic degradation processes (quenching) that occurs during sample preparation and to ensure the stability of ATP [42]. Immediately, prior to measurement, the supernatants were brought to ambient temperature $\left(\sim 23^{\circ} \mathrm{C}\right)$ and the ATP concentration from each sample aliquot was measured by luminometry using Molecular Probes ${ }^{\circledR}$ ATP Determination
Kit. This assay based on luciferase's absolute requirement for ATP in producing light is extremely sensitive: it enables the detection of as little as 0.1 picomole of preexisting ATP. Luminescence was measured in $100 \mu$ reaction mixture containing $500 \mu \mathrm{M}$ luciferin and $1.25 \mu \mathrm{g} / \mathrm{ml}$ luciferase at room temperature with microplate reader FLUOstar Omega (Ortenberg, Germany).

\section{Determination of ecto-ATPase activity}

For determination of ecto-ATPase activity, hydrolysis of exogenously added ATP was determined. SH-SY5Y cells were seeded onto collagen-coated 24-well plates at the density of $1.5 \times 10^{5}$ cells $/ \mathrm{ml}$. After $24 \mathrm{~h}$, the culture medium was carefully changed into $300 \mu \mathrm{l}$ of HBSS with $5 \mathrm{mM}$ HEPES $(\mathrm{pH} 7.4)$ and cells were preincubated for $60 \mathrm{~min}$ at $37^{\circ} \mathrm{C}$. Then, ASN $(10 \mu \mathrm{M})$ was carefully added to the cells. Incubation with ASN was performed in the presence and absence of $50 \mu \mathrm{M}$ ARL 67156, a selective ecto-ATPase inhibitor, in order to check the specific ecto-ATPase-dependent ATP degradation. The assay was initiated by addition of ATP $(100 \mu \mathrm{M})$ to SH-SY5Y cells. After $15 \mathrm{~min}$ of incubation at $37{ }^{\circ} \mathrm{C}, 100 \mu \mathrm{l}$ of incubation media was collected into Eppendorf tubes, placed at $99{ }^{\circ} \mathrm{C}$ for $2 \mathrm{~min}$, and centrifuged $\left(4^{\circ} \mathrm{C}, 800 \times \mathrm{g}, 10 \mathrm{~min}\right)$. Immediately prior to measurement, the supernatants were brought to ambient temperature $\left(\sim 23{ }^{\circ} \mathrm{C}\right)$ and the ATP concentration from each sample aliquot was measured by luminometry using Molecular Probes ${ }^{\circledR}$ ATP Determination Kit. Specific ATP degradation by ectoATPase was calculated by subtracting the results obtained without ARL 67156 from the ones determined in the presence of ARL 67156. The data were presented as micromole ATP per minute.

\section{Statistical analysis}

The results that were expressed as mean values \pm Standard Error of Mean (SEM); differences between the means were analyzed using a Student's $t$ test between two groups or oneway analysis of variance (ANOVA) with Bonferroni multiple comparison post-hoc test among multiple groups. Statistical significance was accepted at $p<0.05$. The statistical analyzes were performed using GraphPad Prism version 4.0 (GraphPad Software, San Diego, CA).

\section{Results}

Since extracellular ASN was previously shown to induce changes in purinergic receptors expression and activity in microglial cells [12], we first verified whether this protein affects mRNA and protein level, as well as the activity of selected P2 receptors subtypes in neuronal cells. We used 
human neuroblastoma SH-SY5Y cell line, and because these cells are able to express a number of features characteristic for catecholaminergic neurons, including tyrosine hydroxylase and dopamine- $\beta$-hydroxylase activities [43], they express various $\mathrm{P} 2$ receptors belonging to both $\mathrm{P} 2 \mathrm{X}$ and $\mathrm{P} 2 \mathrm{Y}$ families as well [44]. From the whole range of purinergic P2X ionotropic and P2Y metabotropic receptors, we have chosen to study few that were previously shown to be connected with neurodegeneration [13].

In the current study, we observed that a 24-h treatment with exogenous ASN $(10 \mu \mathrm{M})$ did not change the mRNA level of the P2X4, P2X7, P2Y1, and P2Y2 receptors (Fig. 2a), as well as had no influence on the immunoreactivity of selected P2X7 and P2Y1 receptors (Fig. 2b). In order to investigate the functional impact of ASN treatment on $\mathrm{P} 2 \mathrm{X}$ receptors coupled to activation of $\mathrm{Ca}^{2+}$ channels, we used PPADS, a widely used non-selective $\mathrm{P} 2 \mathrm{X}$ receptor antagonist. Treatment of SHSY5Y cells with $10 \mu \mathrm{M}$ ASN resulted in significant $\left[\mathrm{Ca}^{2+}\right]_{i}$ mobilization and pretreatment with $100 \mu \mathrm{M}$ PPADS for $2 \mathrm{~min}$, followed by exposure to ASN, almost completely abolished the effect of this protein on $\left[\mathrm{Ca}^{2+}\right]_{i}$ (Fig. 2c, d). In order to determine whether the increase of $\left[\mathrm{Ca}^{2+}\right]_{i}$ is related to metabotropic P2Y receptor-mediated $\mathrm{Ca}^{2+}$ release from endoplasmic reticulum (ER), SH-SY5Y cells were treated with ASN in a calcium-free medium containing additional $\mathrm{Ca}^{2+}$-chelator, EGTA. In those experimental conditions, we observed that exogenous ASN had no impact on $\left[\mathrm{Ca}^{2+}\right]_{i}$ mobilization. Moreover, depletion of ER $\mathrm{Ca}^{2+}$ stores with $10 \mathrm{nM}$ THAPS, a sarco/endoplasmic reticulum $\mathrm{Ca}^{2+}$ ATPase (SERCA) inhibitor, led to a significant enhancement of $\left[\mathrm{Ca}^{2+}\right]_{i}$ level in SHSY5Y cells treated with ASN, compared to untreated cells (Fig. 2e, f). Also, SH-SY5Y cells pretreated with selective P2Y1 receptor antagonist, MRS $2279(10 \mu \mathrm{M})$ did not reverse ASN-evoked changes in $\left[\mathrm{Ca}^{2+}\right]_{i}$ mobilization and were comparable to the effects of ASN treatment alone (Fig. 2g, h). These data suggest that $\mathrm{P} 2 \mathrm{X}$-mediated $\mathrm{Ca}^{2+}$ influx, but not P2Y-related ER stores mobilization, is involved in $\left[\mathrm{Ca}^{2+}\right]_{i}$ increase after ASN treatment.

Among other P2X receptors expressed by SH-SY5Y cells, we focused on P2X4 and P2X7, because they share some functional features and were previously shown to be involved in apoptosis of neuronal cells [33, 45-47]. We analyzed the influence of selective antagonists of P2X7 (AZ 11645373) and P2X4 (5-BDBD) receptors on ASN-induced $\left[\mathrm{Ca}^{2+}\right]_{i}$ mobilization. Pretreatment with $10 \mu \mathrm{M}$ AZ 11645373 almost completely abolished the effect of ASN on $\left[\mathrm{Ca}^{2+}\right]_{i}$ (Fig. 3a), whereas the effect of 5-BDBD was negligible (Fig. 3b), suggesting that the observed $\left[\mathrm{Ca}^{2}{ }^{+}\right]_{i}$ changes were mediated by activation of $\mathrm{P} 2 \mathrm{X} 7$ receptor. For further evidence of the involvement of $\mathrm{P} 2 \mathrm{X} 7$ receptor in the fast $\left[\mathrm{Ca}^{2+}\right]_{i}$ mobilization, induced by ASN, we performed the measurements of ${ }^{[45]} \mathrm{Ca}^{2+}$ uptake, which reflects the influx of extracellular $\mathrm{Ca}^{2+}$ into the cells. A P2X7 receptor stimulation, evoked by the addition of
$5 \mathrm{mM}$ ATP, produced a significant increase in ${ }^{[45]} \mathrm{Ca}^{2+}$ influx. Application of $10 \mu \mathrm{M}$ ASN potentiated the ${ }^{[45]} \mathrm{Ca}^{2+}$ uptake to $170 \%$ of the control, and this effect was comparable with the same observed for ATP. Moreover, both non-selective (PPADS) and selective (AZ 11645373) antagonists of P2X7 receptor significantly reduced the effect of ASN and ATP treatment on ${ }^{[45]} \mathrm{Ca}^{2+}$ influx (Fig. 3c). To confirm that the observed phenomena are not only characteristic for cultured cells of tumor origin, we conducted the ex vivo experiments in synaptic nerve ending-enriched fraction isolated from rat brain. The results were similar to those observed in $\mathrm{SH}-$ SY5Y cells and showed that pretreatment with AZ 11645373 or PPADS prevented ${ }^{[45]} \mathrm{Ca}^{2+}$ influx induced by either ASN or ATP (Fig. 3d), thus conclusively evidenced the participation of $\mathrm{P} 2 \mathrm{X} 7$ in the $\mathrm{Ca}^{2+}$ imbalance caused by exogenous ASN.

Considering the controlling mechanisms of $\mathrm{P} 2 \mathrm{X} 7$ receptor activation, ASN-mediated release of ATP from the cells is possibly involved in the $\mathrm{P} 2 \mathrm{X} 7$-mediated deregulation of $\left[\mathrm{Ca}^{2+}\right]_{i}$. Our biochemical experiments showed that 1-min treatment with exogenous ASN increased almost twofold the amount of extracellular ATP (Fig. 4a). Upon a variety of stimulations, ATP can be released by membrane transporters, particularly, pannexin channels (Panx) [48]. To block ATP release from cells, we used carbenoxolone (CBX; $10 \mu \mathrm{M})$, a selective inhibitor of Panx1, and observed that this compound normalized extracellular ATP levels in SH-SY5Y cells treated with ASN. P2X7 receptor blockade with AZ 11645373 also resulted in significant reduction of the extracellular ATP release after ASN treatment (Fig. 4a). Moreover, pretreatment with CBX had no effect on either elevation of $\left[\mathrm{Ca}^{2+}\right]_{i}$ in SH-SY5Y cells (Fig. 4b, c) or ${ }^{\left[{ }^{45}\right]} \mathrm{Ca}^{2+}$ influx in rat brain synaptoneurosomes (Fig.4d) induced by ASN. This indicated that ATP release by Panx is not responsible for $\mathrm{P} 2 \mathrm{X} 7$ receptor activation induced by ASN treatment. To further confirm that ASN could directly affect the $\mathrm{P} 2 \mathrm{X} 7$ receptor function, we treated the cells with apyrase (EC 3.6.1.5), a calcium-activated enzyme that catalyzes the hydrolysis of ATP to AMP and inorganic phosphate. We observed that in the presence of apyrase, the extracellular ATP level was almost completely reduced in SH-SY5Y cells treated with ASN, and this decrease was proportional to the applied dose of apyrase (Fig. 5a). In the conditions of $90 \%$ extracellular ATP withdrawal (pretreatment with apyrase at the dose of $1 \mathrm{U}$ ), the effect of exogenous ASN on $\left[\mathrm{Ca}^{2+}\right]_{i}$ mobilization in SH-SY5Y cells was similar to this observed in the absence of apyrase (Fig. 5b, c). Moreover, in the presence of apyrase, AZ 11645373 was still able to reduce the effect of ASN treatment on $\left[\mathrm{Ca}^{2+}\right]_{i}$ (Fig. $5 \mathrm{~b}, \mathrm{c}$ ). Similar results were observed in ex vivo experiments in synaptic nerve endings and showed that the significant reduction of extracellular ATP did not change the effect of ASN on ${ }^{[45]} \mathrm{Ca}^{2+}$ influx in a 
A

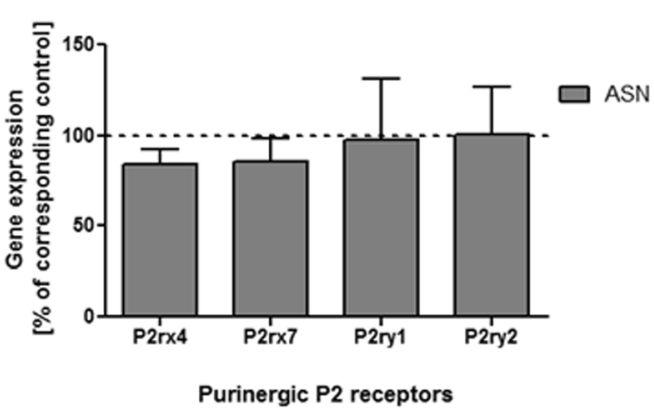

B

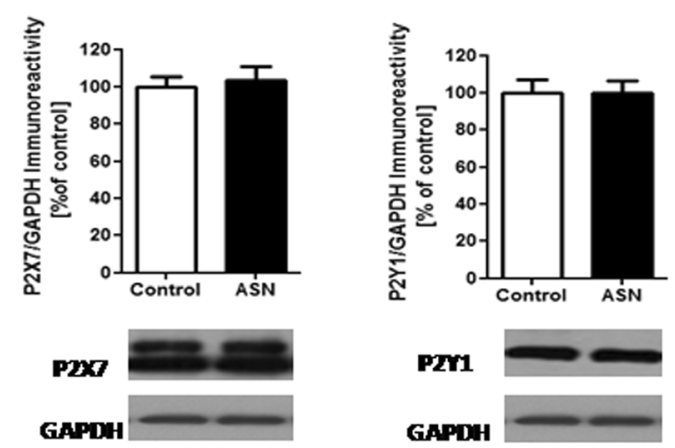

GAPDH
C
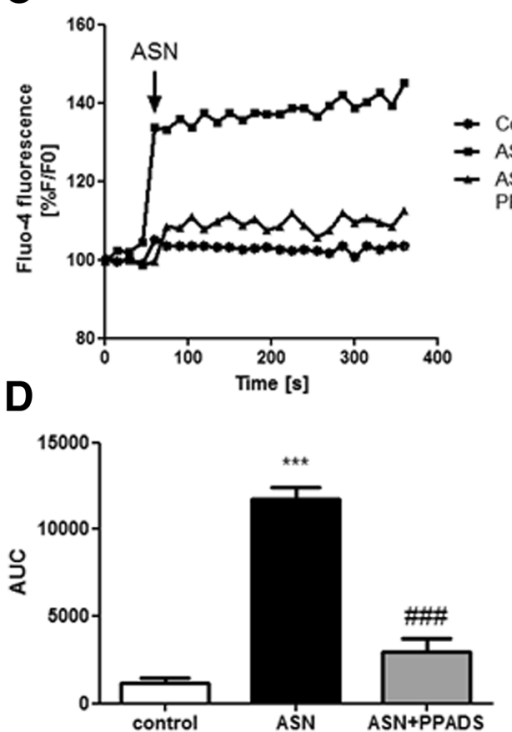

E

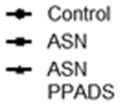
PPADS

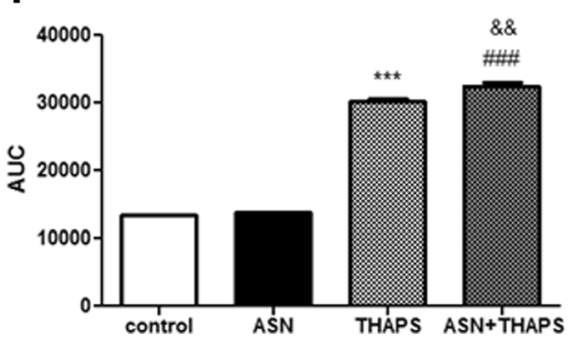

G

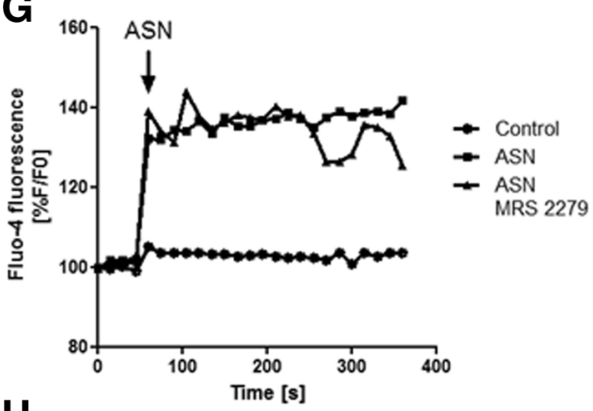

H

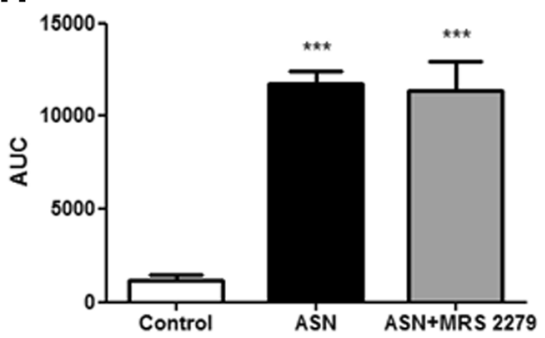

Fig. 2 The effect of extracellular ASN treatment on the expression and activity of purinergic $\mathrm{P} 2$ receptors. a Gene expression for $\mathrm{P} 2$ receptors was analyzed by quantitative RT-PCR after $24 \mathrm{~h}$ treatment with ASN $(10 \mu \mathrm{M})$ in culture medium containing $2 \%$ FBS. Data are expressed as a percent of corresponding control and represent the mean value \pm SEM for three separate experiments $(n=3)$. b Immunoreactivity of P2X7 and P2Y1 receptors was analyzed by SDS-PAGE and Western blotting after $24 \mathrm{~h}$ treatment with ASN $(10 \mu \mathrm{M})$ in culture medium containing $2 \% \mathrm{FBS}$. Representative pictures were shown. Results of densitometric analysis were normalized to immunoreactivity of GAPDH, as a loading control. The results are presented as the mean \pm SEM from seven independent experiments $(n=7)$. c SH-SY5Y cells were preincubated for $60 \mathrm{~s}$ with $100 \mu \mathrm{M}$ PPADS (P2 receptors antagonist) in HBSS. Baseline Fluo-4 fluorescence was monitored for $60 \mathrm{~s}$ prior to the addition of ASN $(10 \mu \mathrm{M})$. Fluorescence was monitored for a further $300 \mathrm{~s}$ and values were converted to $\% \mathrm{~F} / \mathrm{F} 0$, where $\mathrm{F} 0$ is the fluorescence value of first record $(0 \mathrm{~s})$. d Responses were quantitated by measuring the AUC value. The results are presented as the mean \pm SEM from six independent experiments $(n=6)$. ***p $<0.001$ versus control, $\# \# p<0.001$ versus ASN-treated cells using a one-way ANOVA followed by the Bonferroni test. e SH-SY5Y cells were preincubated

for $60 \mathrm{~s}$ in calcium-free HBSS buffer containing $10 \mathrm{mM}$ Tris and $1 \mathrm{mM}$ EGTA. Baseline Fluo-4 fluorescence was monitored for $60 \mathrm{~s}$ prior to the addition of ASN $(10 \mu \mathrm{M})$. Fluorescence was monitored for a further $90 \mathrm{~s}$ (first peak). Then, the calcium influx (second peak) was initiated by the addition of THAPS $(10 \mathrm{nM})$. Values were converted to $\% \mathrm{~F} / \mathrm{F} 0$, where F0 is the fluorescence value of first record $(0 \mathrm{~s})$. $\mathbf{f}$ Responses were quantitated by measuring the AUC value of first and second peak. The results are presented as the mean \pm SEM from three independent experiments

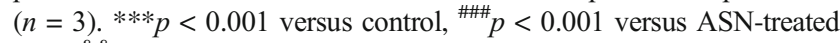
cells, ${ }^{\& \&} p<0.01$ versus THAPS-treated cells using a one-way ANOVA followed by the Bonferroni test. $g$ SH-SY5Y cells were preincubated for $60 \mathrm{~s}$ with $10 \mu \mathrm{M}$ MRS 2279 (P2Y1 receptors antagonist) in HBSS. Baseline Fluo-4 fluorescence was monitored for $60 \mathrm{~s}$ prior to the addition of ASN $(10 \mu \mathrm{M})$. Fluorescence was monitored for a further $300 \mathrm{~s}$ and values were converted to $\% \mathrm{~F} / \mathrm{F} 0$, where $\mathrm{F} 0$ is the fluorescence value of first record $(0 \mathrm{~s})$. $\mathbf{h}$ Responses were quantitated by measuring the AUC value. The results are presented as the mean \pm SEM from three to six independent experiments $(n=3-6)$. $* * * p<0.001$ versus control using a one-way ANOVA followed by the Bonferroni test

EC 3.6.1.3), the major plasma membrane nucleotidase responsible for the hydrolysis of extracellular ATP (Fig. 6a). Moreover, the inhibition of ecto-ATPase with $50 \mu \mathrm{M}$ ARL 67156 resulted in a significant elevation of extracellular ATP level, and the effect of the ecto-adenosine triphosphatase

manner prevented by AZ 11645373 (Fig. 5d), thus conclusively evidenced the direct interaction of exogenous ASN with $\mathrm{P} 2 \mathrm{X} 7$ receptor.

Finally, we observed that ASN significantly decreased the activity of the ecto-adenosine triphosphatase (ecto-ATPase, 

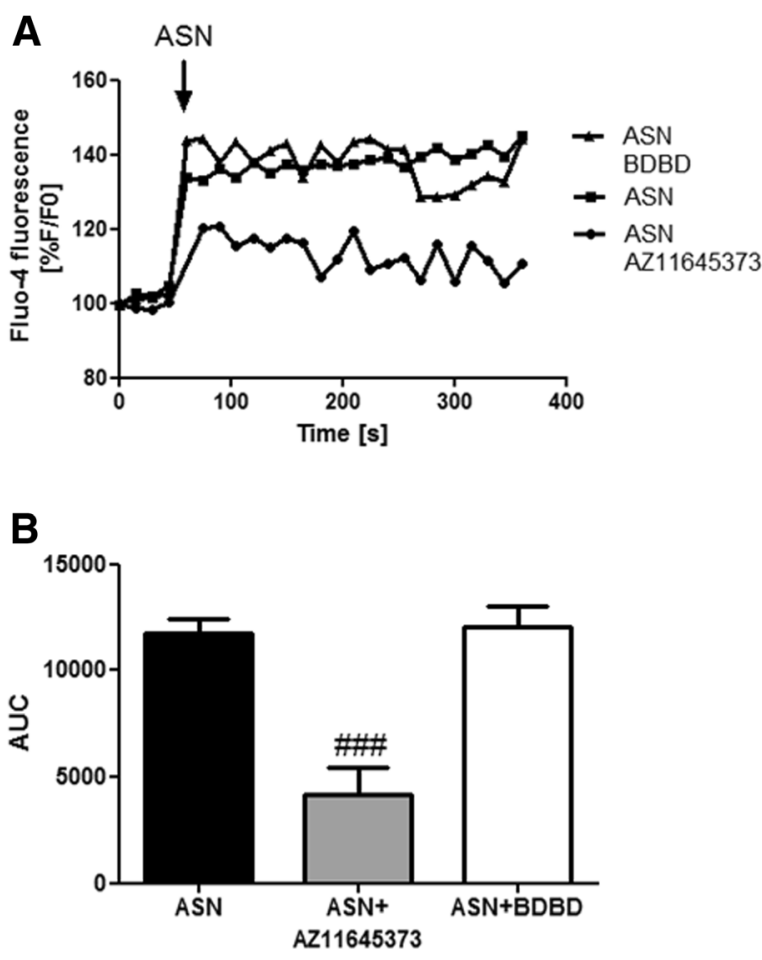

Fig. $3 \mathrm{P} 2 \mathrm{X} 7$, but not $\mathrm{P} 2 \mathrm{X} 4$ receptor, mediates $\mathrm{ASN}$-induced calcium influx. a SH-SY5Y cells were preincubated for $60 \mathrm{~s}$ with $10 \mu \mathrm{M} \mathrm{AZ}$ 11645373 (P2X7 receptors antagonist) or $100 \mu \mathrm{M}$ 5-BDBD (P2X4 receptor antagonist) in HBSS. Baseline Fluo-4 fluorescence was monitored for $60 \mathrm{~s}$ prior to the addition of ASN $(10 \mu \mathrm{M})$. Fluorescence was monitored for a further $300 \mathrm{~s}$, and values were converted to $\% \mathrm{~F} / \mathrm{F} 0$, where $\mathrm{F} 0$ is the fluorescence value of first record $(0 \mathrm{~s})$. b Responses were quantitated by measuring the AUC value. The results are presented as the mean \pm SEM from three to six independent experiments $(n=3-6)$. \#\#\# $p<0.001$ versus ASN-treated cells using a one-way ANOVA followed by the Bonferroni test. c The SH-SY5Y cells were preincubated with $10 \mu \mathrm{M} \mathrm{AZ} 11645373$ or $100 \mu \mathrm{M}$ PPADS for $5 \mathrm{~min}$ in the Locke 5 medium containing 5 mM HEPES (pH 7.4), followed by a

inhibitor was more pronounced when the cells were treated with ASN (Fig. 6b).

\section{Discussion}

In the present study, we have discussed the pivotal role of extracellular ASN in the deregulation of purinergic signaling. Our data have shown that interaction of ASN with P2X7 receptor is responsible for its activation. These findings are thus consistent with previous studies, which demonstrated that ASN leads to activation of microglial P2X7 receptor [12], and those findings are extended by showing that this important interaction occurs also in neuronal cells.

Since neurodegenerative diseases share common features and mechanisms responsible for inducing the death of selective neuronal populations [49-51], the extracellular release of ASN as well as activation of P2 receptor
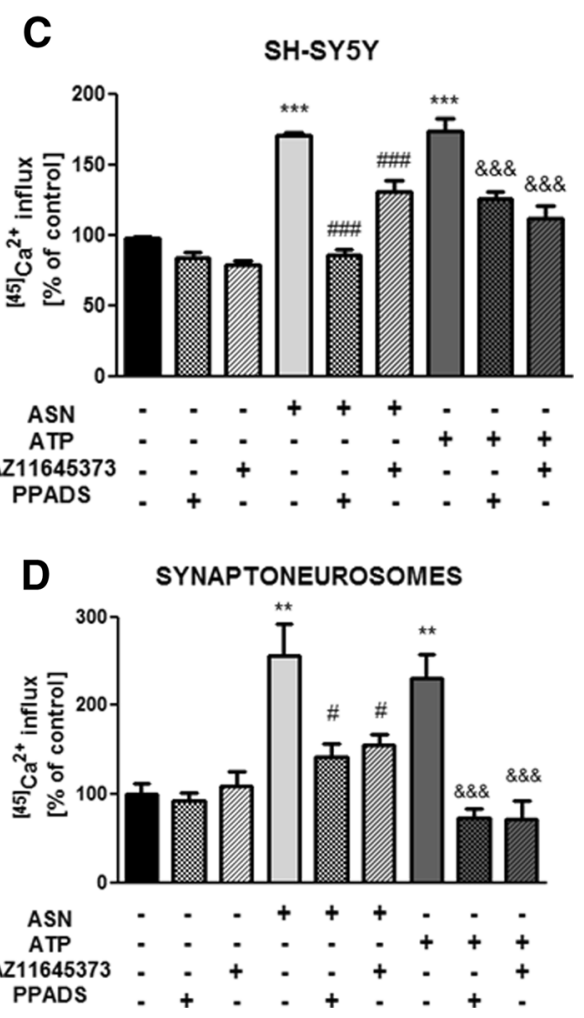

5 min incubation with $10 \mu \mathrm{M}$ ASN or $5 \mathrm{mM}$ ATP. Then, ${ }^{[45]} \mathrm{CaCl}_{2}(1 \mu \mathrm{Ci} /$ well) was added for $10 \mathrm{~min}$. The results are presented as the mean $\pm \mathrm{SEM}$ from three to six independent experiments $(n=3-6)$. *** $p<0.001$ versus

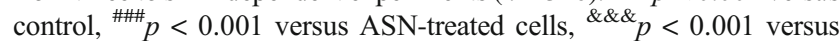
ATP-treated cells using a one-way ANOVA followed by the Bonferroni test. d Rat brain synaptoneurosomes were preincubated with PPADS $(100 \mu \mathrm{M})$ or AZ $11645373(10 \mu \mathrm{M})$ for $5 \mathrm{~min}$, followed by a 30 -min incubation with $10 \mu \mathrm{M}$ ASN or $5 \mathrm{mM}$ ATP at $37^{\circ} \mathrm{C}$ in HBSS medium (pH 7.4). The reaction was started by adding $0.1 \mu \mathrm{Ci}{ }^{[45]} \mathrm{CaCl}_{2}$. The results are presented as the mean \pm SEM from three to six independent experiments $(n=3-6)$. ** $p<0.01$ versus control, ${ }^{\#} p<0.05$ versus ASNtreated cells, \&\&\&p<0.001 versus ATP-treated cells using a one-way ANOVA followed by the Bonferroni test

may likely contribute, alone or in combination, to these mechanisms and to a neurodegenerative process. Purinergic signaling was previously shown to be involved in the etiopathology of many neurodegenerative disorders [52]. Moreover, after metabolic stress, brain ischemia, and trauma, the extracellular ATP and adenosine levels were observed to reach values that were considerably exceeding the ones observed in physiological conditions [14, 53, 54]. Consistently, several P2 receptor antagonists prevented cell death of neurons exposed to oxaliplatin [55], excessive glutamate [56], hypoglycemia [57], and chemical hypoxia [58]. Furthermore, previous studies indicated that an altered activity of the purinergic receptors mediates the proinflammatory processes in a transgenic AD model and in brains from AD patients [27-29] and in vivo inhibition of P2X7 receptors significantly reduces the amyloid plaques formation in brain hippocampal structures through activation of $\alpha$-secretase activity [59]. Moreover, the recent 
A

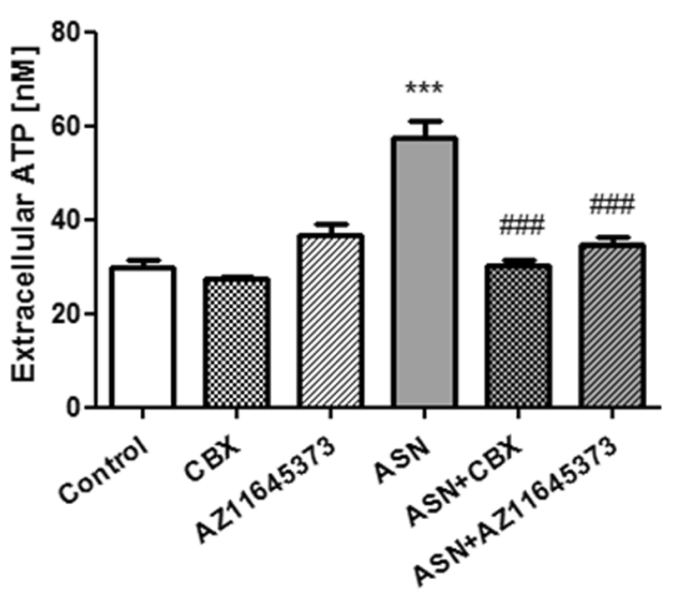

D

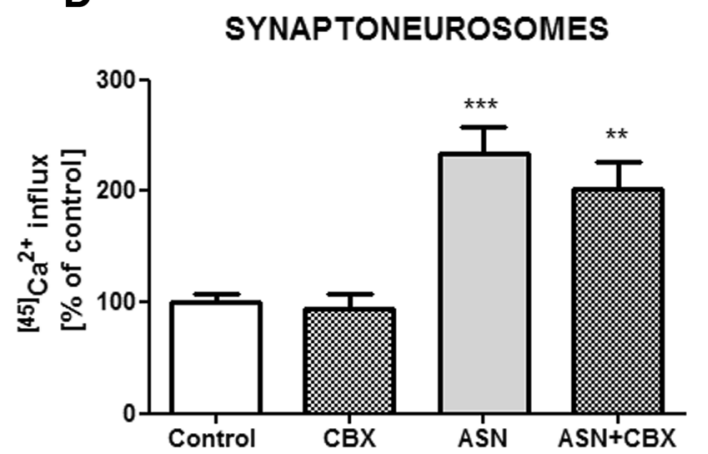

Fig. 4 Activation of $\mathrm{P} 2 \mathrm{X} 7$ receptors leads to pannexin 1-dependent ATP release. a Extracellular ATP level was analyzed after 1-min treatment with $10 \mu \mathrm{M}$ ASN together or without $10 \mu \mathrm{M}$ CBX (antagonist of pannexin channels) or $10 \mu \mathrm{M} \mathrm{AZ} 11645373$ (P2X7 receptors antagonist) at $37^{\circ} \mathrm{C}$ in HBSS with $5 \mathrm{mM}$ HEPES ( $\mathrm{pH}$ 7.4) using the luciferase-based protocol described in the "Materials and methods" section. Data, calculated from respective calibration curves, are expressed as nM ATP and the data represent the mean value \pm SEM for six to eight separate experiments $(n=6-8) . * * * p<0.001$ versus control, ${ }^{\# \#} p<0.001$ versus ASN-treated cells using a one-way ANOVA followed by the Bonferroni test. b SHSY5Y cells were preincubated $(60 \mathrm{~s})$ with $10 \mu \mathrm{M}$ CBX or appropriate solvent in HBSS. Baseline Fluo-4 fluorescence was monitored for $60 \mathrm{~s}$ prior to the addition of $\mathrm{ASN}(10 \mu \mathrm{M})$ or appropriate solvent.

observation that $\mathrm{P} 2 \mathrm{X} 1$ receptor activation induces lysosomal dysfunction and intracellular ASN accumulation puts the role of ATP and P2 receptors as a key event related to misfolded protein response [60]. In the light of these data, we tested whether extracellularly liberated ASN can activate different $\mathrm{P} 2$ receptor subtypes, but our observations indicated that $\mathrm{P} 2 \mathrm{X} 7$ receptor is exclusively affected by this protein.

Deregulation of P2X7 receptor has previously been indicated to be common for diverse situations of brain damage, such as ischemia [61, 62], traumatic brain injury [63], spinal cord injury [64], epilepsy [65], Alzheimer's disease [59, 66], Parkinson's disease [67], prion disease [68], or Huntington's disease [69]. However, in those pathological conditions, the upregulation of this receptor was observed mainly in glial
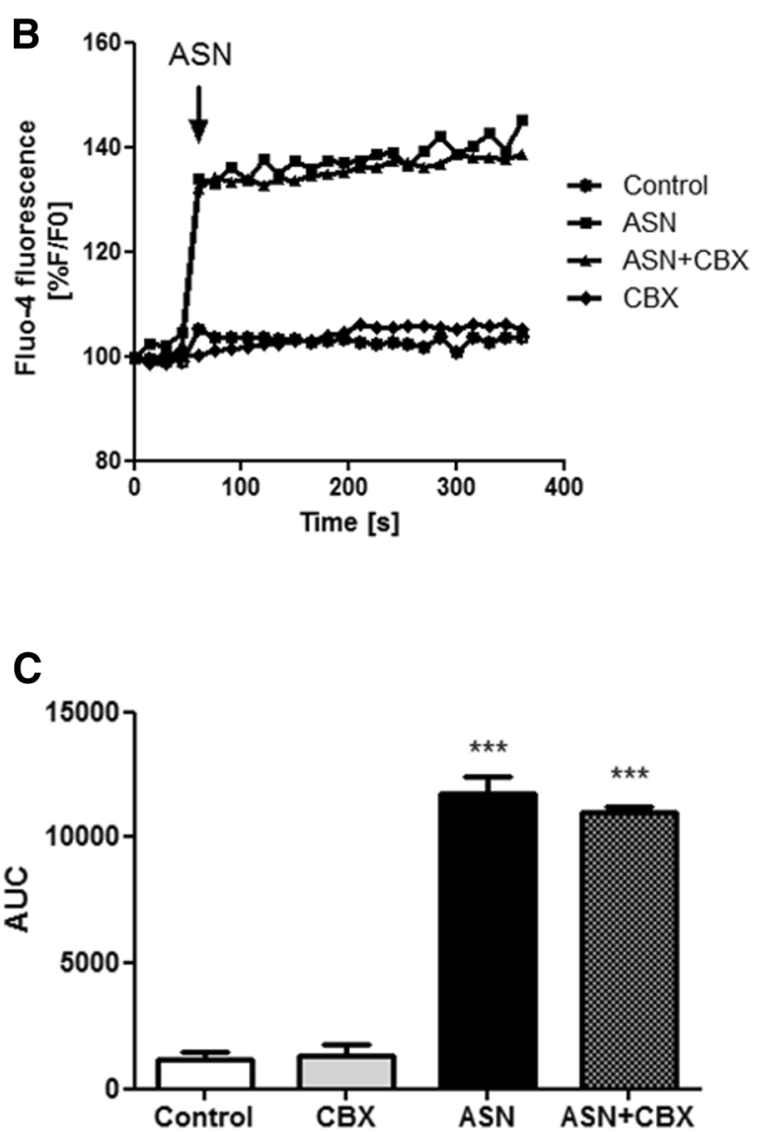

Fluorescence was monitored for a further $300 \mathrm{~s}$, and values were converted to $\% \mathrm{~F} / \mathrm{F} 0$, where $\mathrm{F} 0$ is the fluorescence value of first record $(0 \mathrm{~s})$. $\mathbf{c}$ Responses were quantitated by measuring the AUC value. The results are presented as the mean \pm SEM from four to six independent experiments $(n=4-6)$. $* * * p<0.001$ versus control using a one-way ANOVA followed by the Bonferroni test. $\mathbf{d}$ Rat brain synaptoneurosomes were preincubated with $\mathrm{CBX}(10 \mu \mathrm{M})$ for $5 \mathrm{~min}$, followed by a 30 -min incubation with $10 \mu \mathrm{M}$ ASN at $37^{\circ} \mathrm{C}$ in HBSS medium (pH 7.4). The reaction was started by adding $0.1 \mu \mathrm{Ci}{ }^{[45]} \mathrm{CaCl}_{2}$. The results are presented as the mean \pm SEM from three to six independent experiments $(n=3-6) . * * p<0.01, * * * p<0.001$ versus control using a one-way ANOVA followed by the Bonferroni test

cells, where P2X7 is ubiquitously expressed [29, 70-75]. Since this receptor was shown to be an obligate participant in microglia activation caused by amyloid beta and ASN [12, 76, 77], the P2X7R-mediated neurotoxicity was connected mostly to the control of the noxious impact of glial cells on neuronal viability. However, recent data also suggest that $\mathrm{P} 2 \mathrm{X} 7 \mathrm{R}$ is functionally expressed by neuronal cells and its activation has a direct impact on neuronal cell death $[33,67]$. Although our data ultimately excluded the involvement of extracellular ASN in changes of P2X7 receptor expression, they showed that it has a powerful impact on this receptor's activity in neuronal cells.

Among P2 nucleotide receptors, P2X7 exhibits low sensitivity to ATP, and its maximal activity is achieved with as far as millimolar concentrations [78, 79]. It was initially 
A
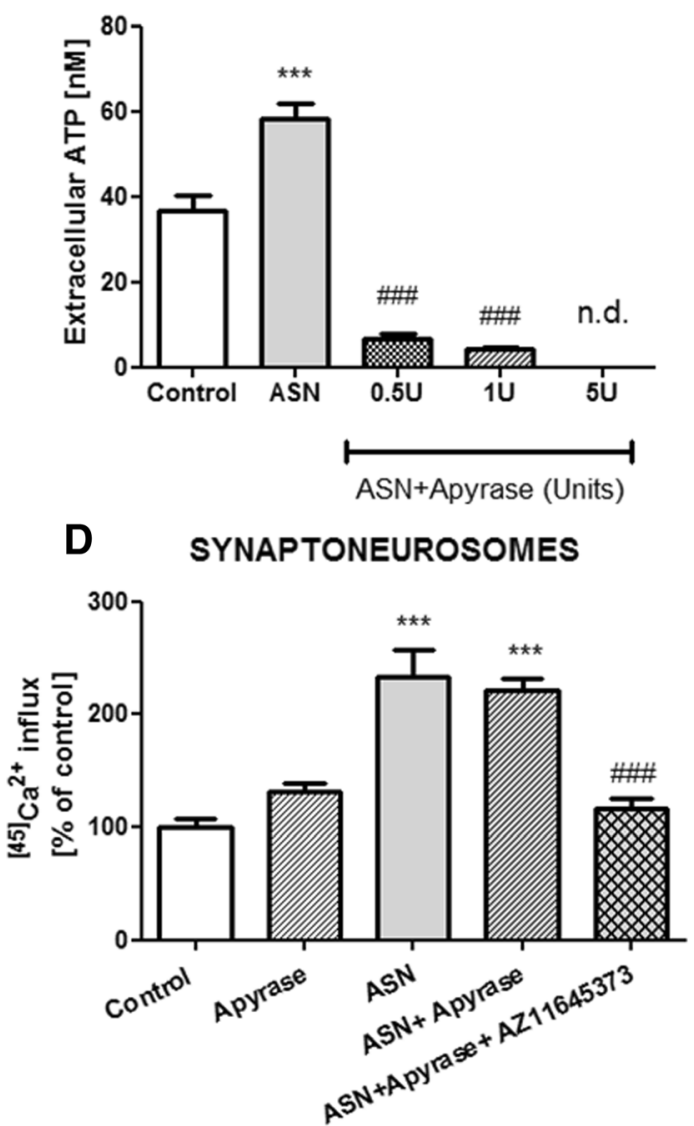

Fig. 5 The increase in extracellular ATP by ASN is not responsible for P2X7 receptor activation. a Extracellular ATP level was analyzed after 1min treatment with $10 \mu \mathrm{M}$ ASN together or without $0.5,1$, or $5 \mathrm{U}$ apyrase at $37^{\circ} \mathrm{C}$ in HBSS with $5 \mathrm{mM}$ HEPES (pH 7.4) using the luciferase-based protocol described in the "Materials and methods" section. Data, calculated from respective calibration curves, are expressed as nM ATP and the data represent the mean value \pm SEM for three separate experiments $(n=3)$. ***p ${ }^{*} 0.001$ versus control, ${ }^{\# \#} p<0.001$ versus ASN-treated cells using a one-way ANOVA followed by the Bonferroni test. b SH-SY5Y cells were preincubated (60 s) with $1 \mathrm{U}$ apyrase with or without $10 \mu \mathrm{M}$ AZ 11645373 (P2X7 receptors antagonist) or appropriate solvent in HBSS. Baseline Fluo-4 fluorescence was monitored for $60 \mathrm{~s}$ prior to the addition of ASN $(10 \mu \mathrm{M})$ or appropriate solvent.

suggested that the high concentrations of extracellular ATP, required to stimulate cytotoxic actions of this receptor, might not be reached in vivo. However, there is evidence that different noxious brain stimuli are able to substantially increase the extracellular levels of ATP [61, 80-83]. Moreover, damaged neurons are also the source of considerable amounts of released ATP that may act as a "find me" signal for microglial cells [32], which then release excess amounts of reactive oxygen species (ROS), proinflammatory cytokines, etc. [84, 85]. Such high concentrations of ATP existing in pathological conditions also exert direct toxic effect on primary neuronal cultures and organotypic CNS cultures [33]. Therefore,

\section{B}
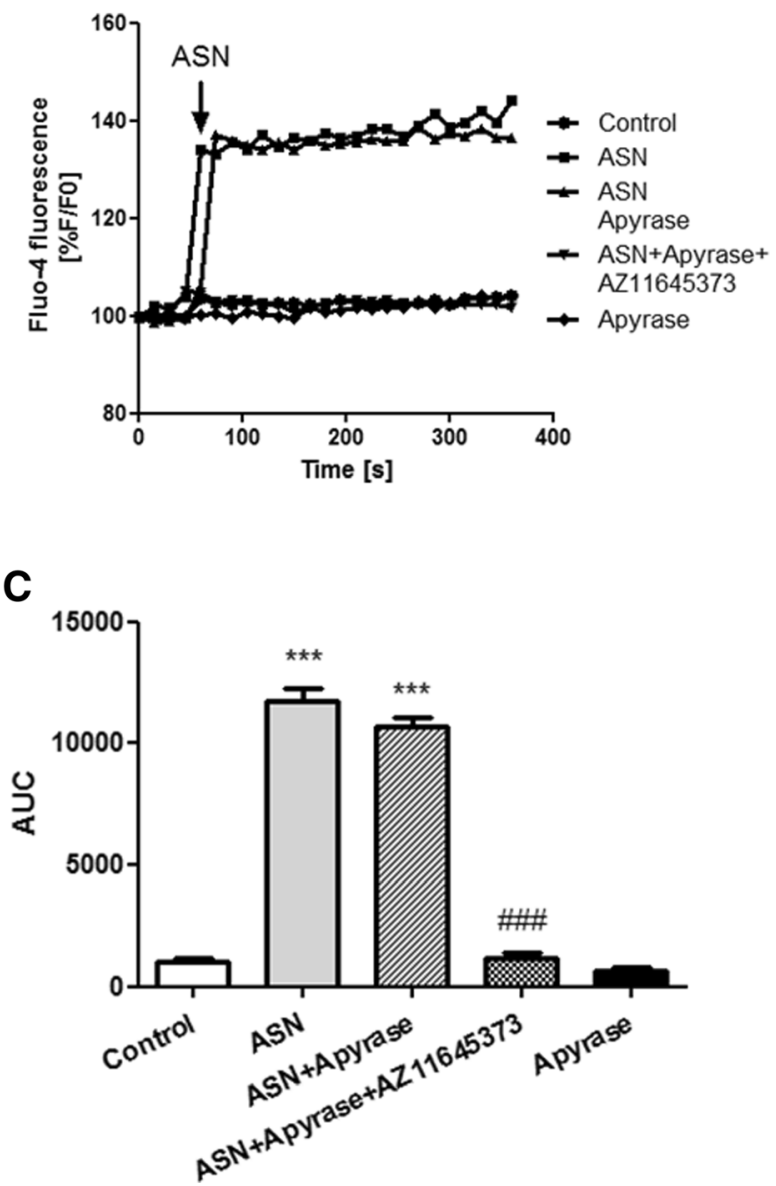

Fluorescence was monitored for a further $300 \mathrm{~s}$, and values were converted to $\% \mathrm{~F} / \mathrm{F} 0$, where $\mathrm{F} 0$ is the fluorescence value of first record (0 s). c Responses were quantitated by measuring the AUC value. The results are presented as the mean \pm SEM from four independent experiments $(n=4)$. *** $p<0.001$ versus control, ${ }^{\# \# \#} p<0.001$ versus ASN-treated cells using a one-way ANOVA followed by the Bonferroni test. d Rat brain synaptoneurosomes were preincubated with $1 \mathrm{U}$ apyrase with or without $10 \mu \mathrm{M}$ AZ 11645373 for $5 \mathrm{~min}$, followed by a 30-min incubation with $10 \mu \mathrm{M}$ ASN at $37^{\circ} \mathrm{C}$ in $\mathrm{HBSS}$ medium (pH 7.4). The

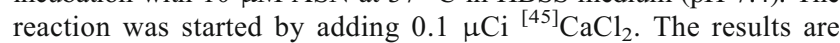
presented as the mean $\pm \mathrm{SEM}$ from three independent experiments $(n=3) .{ }^{*} * *<0.001$ versus control, ${ }^{\# \#} p<0.001$ versus ASN-treated cells using a one-way ANOVA followed by the Bonferroni test

pathophysiological role of extracellular ATP in the regulation of ASN-induced P2X7 receptor dysfunction seemed plausible. In this study, we have observed that substantial increase in ATP secretion from SH-SY5Y cells is associated with ASN treatment. Among several membrane proteins that have been proposed to mediate ATP release, we put special emphasis on the Panx1 channel that does not form functional gap junctions, but is responsible for the release of signaling molecules to extracellular space $[86,87]$. Many previous data indicated that Panx 1 is expressed in neuronal and epithelial tissues where it mediates ATP release [87]. Recently, it has been reported that Panx1-dependent ATP release from apoptotic cells is a 


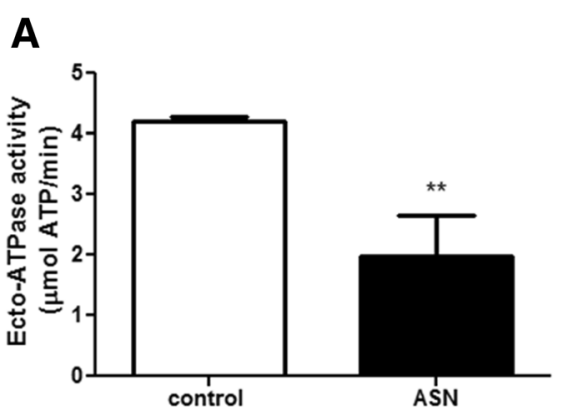

Fig. 6 Extracellular ASN decreases the activity of ecto-ATPase in SHSY5Y cells. a Hydrolysis of exogenously added ATP $(100 \mu \mathrm{M})$ by the SH-SY5Y cells treated for $10 \mathrm{~min}$ with $10 \mu \mathrm{M}$ ASN in the presence/ absence of $50 \mu \mathrm{M}$ ARL 67156 (ecto-ATPase inhibitor) was determined by luminometry analysis described in the "Materials and methods" section. Data, calculated from respective calibration curve, are expressed as $\mu \mathrm{M}$ of hydrolyzed ATP per min and they represent the mean value \pm SEM for three separate experiments $(n=3) .{ }^{* *} p<0.01$ versus control by Student's $t$ test. b Extracellular ATP level was analyzed

mechanism responsible for phagocyte recruitment [16]. Moreover, Panx1 may indirectly contribute to neuronal death by activating a large protein complex called the inflammasome [88]. Previously, the linkage between P2X7 receptor and Panx1 was also considered to be necessary for P2X7-mediated generation of ROS and proinflammatory cytokines in macrophages $[89,90]$. On the other hand, neurons also express both P2X7 and Panx1, but their functionality remains controversial [91-93]. Our current studies have shown that inhibition of Panx1 dampens extracellular ATP levels; however, it does not inhibit P2X7 receptor activity. Moreover, we observed that the selective antagonist of P2X7 receptor is also capable of inhibiting ATP release from $\mathrm{SH}-$ SY5Y cells. Those results suggested that $\mathrm{P} 2 \mathrm{X} 7$ receptor activation by ASN is responsible for Panx1-dependent ATP release. Indeed, previous reports demonstrated that ATP acting through P2X7 receptor can activate Panx1 channels, enabling the phenomenon of ATP-induced ATP release and thereby amplifying the ATP signal [78]. The mechanism of Panx1 activation by $\mathrm{P} 2 \mathrm{X} 7$ receptor has been previously described to be independent of calcium influx [94], but strongly dependent on Src tyrosine kinase activation, following P2X7 receptor stimulation [95]. Moreover, prolonged or repeated activation of Panx1 by P2X7 receptor results in cell death [94], but direct stimulation of Panx1 is not sufficient to induce toxicity per se [96]. Thus, Panx 1 appears to be the molecular substrate for the permeabilization pore recruited into the P2X7 signaling complex. Therefore, direct interaction of extracellular ASN with P2X7 subunits, leading to conformational change of the receptor, might be the mechanism responsible for its activation. This hypothesis is evidenced by the previous study that show coimmunoprecipitation of ASN with $\mathrm{P} 2 \mathrm{X} 7$ receptor [12]. Moreover, we observed that in the conditions of extracellular ATP withdrawal, the exogenous ASN is still able to
B

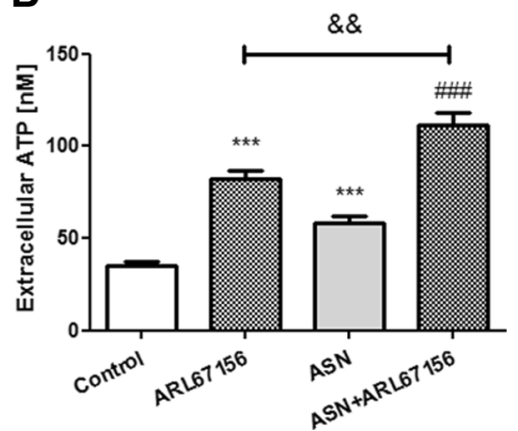

after 1-min treatment with $10 \mu \mathrm{M}$ ASN together or without $50 \mu \mathrm{M}$ ARL 67156 at $37{ }^{\circ} \mathrm{C}$ in HBSS with $5 \mathrm{mM}$ HEPES (pH 7.4) using the luciferase-based protocol described in the "Materials and methods" section. Data, calculated from respective calibration curves, are expressed as nM ATP and the data represent the mean value \pm SEM for three separate experiments $(n=3)$. $* * * p<0.001$ versus control,

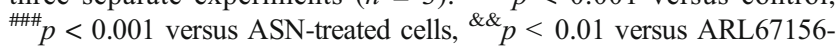
treated cells using a one-way ANOVA followed by the Bonferroni test

activate $\mathrm{P} 2 \mathrm{X} 7$ receptor and this effect is reversed by selective inhibitor of P2X7. Based on those results, we can speculate that exogenous ASN can directly activate $\mathrm{P} 2 \mathrm{X} 7$ receptor leading to Panx1 recruitment to form an active complex responsible for ATP release in cultured neuronal cells. Though, sustained ATP release from neurons may further autostimulate P2X7 receptors located in the same or neighboring cells, yet the abundance of local nucleotidases can greatly limit the available concentration of ATP by rapidly converting the ATP released from adjacent cells into adenosine [14]. Interestingly, the extracellular catabolism of ATP by ecto-nucleotidases, followed by activation of adenosine receptors, may constitute the indirect impact of ATP on brain dysfunction. This seems to be especially important in the pathology of $\mathrm{PD}$, since a specific synergism between stimulation of D2 receptors and inhibition of adenosine $\mathrm{A} 2 \mathrm{~A}$ receptors (A2AR) was previously indicated [97]. Moreover, the expression of A2AR in the brain of patients with PD and dyskinesia was increased [98], and in a rat model of PD, adenosine A1, dopamine D1, and glutamate mGlu5 receptors have been shown to interact during locomotion [99]. Followed by those observations, recent data have shown that exogenous ASN treatment triggers selective induction of A2AR expression in both the primary neuronal cells [100] and the animal models of synucleinopathy [101]. In those studies, the genetic deletion of A2AR prevented ASN-induced changes, such as astrogliosis, NF-KB activation, apoptotic neuronal cell death, and impairment of LTP, and prevented from the memory deficits. Intriguingly, blockade of A2AR increased oligomerization of ASN [101], but at the same time, it reduced percentage of cells displaying ASN inclusions [100]. Taken together, those observations may suggest that ASN-induced sustained ATP release from neuronal cells, followed by its extracellular catabolism to adenosine, may 
result in a parallel bolstering of the ATPergic and adenosinergic arms of the purinergic system, leading to stimulation of cytotoxic effects of purinergic signaling on neighboring microglia, astrocytes, and neurons [14]. Interestingly, our recent observations showed that extracellular ASN greatly decreases the activity of ecto-ATPase that, on one hand, may result in the increase of extracellular ATP content reaching to millimolar concentration, but on the other, this may substantially decrease the formation of ATP-derived adenosine. Since abundance of adenosine is critical for A2AR activation, the obtained results seem to be inconsistent with the overall hypothesis of purinergic deregulation evoked by exogenous ASN. The most probable explanation of this discrepancy might be that the ecto-5'-nucleotidase (CD73, EC 3.1.3.5), the major enzyme able to convert extracellular AMP into adenosine, is more important for the adenosine A2A receptor activation than ecto-ATPase-dependent extracellular ATP catabolism. Indeed, it was demonstrated that CD73 colocalizes with A2AR in the postsynaptic sites of basal ganglia and the CD73 activation is necessary for A2AR-dependent cAMP formation in synaptic terminals [102]. It is also probable that exogenous ASN might inhibit ecto-ATPase while activating CD73; however, this relevant interaction remains to be studied.

In summary, our data is the first to show that interaction between ASN and purinergic $\mathrm{P} 2 \mathrm{X} 7$ receptor occurs in neuronal cells. Moreover, our results reveal that P2X7/Panx1dependent dynamic change of extracellular ATP and inhibition of ATP degradation are key molecular processes involved in extracellular ASN-mediated deleterious signaling. Those new observations, supplemented with the latest studies from other groups, provide the evidence for anti-purinergic therapy that can be an effective treatment of neurodegenerative disorders.

\begin{abstract}
Acknowledgements Financial support was provided by the National Science Center grant 2013/09/D/NZ3/0135 to A.W. The sponsors of this study were not involved in the study design; in collection, analysis, and interpretation of data; in the writing of the report; or in the decision to submit the paper for publication. The authors would like to thank Dr. Julita Nowakowska at Laboratory of Electron and Confocal Microscopy, Faculty of Biology, University of Warsaw, for the invaluable help in performing TEM analysis.
\end{abstract}

\section{Compliance with ethical standards}

Conflict of interest Anna Wilkaniec declares that she has no conflict of interest.

Magdalena Gąssowska declares that she has no conflict of interest. Grzegorz A. Czapski declares that he has no conflict of interest. Magdalena Cieślik declares that she has no conflict of interest. Grzegorz Sulkowski declares that he has no conflict of interest. Agata Adamczyk declares that she has no conflict of interest.
Ethical approval All the experiments conducted on the animals were approved by the IV Local Ethics Committee for Animal Experimentation in Warsaw and were carried out in accordance with the EC Council Directive of November 24, 1986 (86/609/EEC), following the ARRIVE guidelines and guidelines published in the NIH Guide for the Care and Use of Laboratory Animals and the principles presented in the "Guidelines for the Use of Animals in Neuroscience Research" by the Society for Neuroscience.

Open Access This article is distributed under the terms of the Creative Commons Attribution 4.0 International License (http:// creativecommons.org/licenses/by/4.0/), which permits unrestricted use, distribution, and reproduction in any medium, provided you give appropriate credit to the original author(s) and the source, provide a link to the Creative Commons license, and indicate if changes were made.

\section{References}

1. Wilkaniec A, Strosznajder JB, Adamczyk A (2013) Toxicity of extracellular secreted alpha-synuclein: its role in nitrosative stress and neurodegeneration. Neurochem Int 62(5):776-783. doi:10. 1016/j.neuint.2013.02.004

2. Spillantini MG, Schmidt ML, Lee VMY, Trojanowski JQ, Jakes R, Goedert M (1997) [alpha]-Synuclein in Lewy bodies. Nature 388(6645):839-840

3. Lee H-J, Bae E-J, Lee S-J (2014) Extracellular $\alpha$-synuclein-a novel and crucial factor in Lewy body diseases. Nat Rev Neurol 10(2):92-98. doi:10.1038/nrneurol.2013.275

4. Lee HJ, Suk JE, Bae EJ, Lee SJ (2008) Clearance and deposition of extracellular alpha-synuclein aggregates in microglia. Biochem Biophys Res Commun 372(3):423-428. doi:10.1016/j.bbrc.2008. 05.045

5. Gassowska M, Czapski GA, Pajak B, Cieslik M, Lenkiewicz AM, Adamczyk A (2014) Extracellular alpha-synuclein leads to microtubule destabilization via GSK-3beta-dependent Tau phosphorylation in PC12 cells. PLoS One 9(4):e94259. doi:10.1371/journal. pone.0094259

6. Czapski GA, Gassowska M, Wilkaniec A, Cieslik M, Adamczyk A (2013) Extracellular alpha-synuclein induces calpain-dependent overactivation of cyclin-dependent kinase 5 in vitro. FEBS Lett 587(18):3135-3141. doi:10.1016/j.febslet.2013.07.053

7. Adamczyk A, Kazmierczak A, Czapski GA, Strosznajder JB (2010) Alpha-synuclein induced cell death in mouse hippocampal (HT22) cells is mediated by nitric oxide-dependent activation of caspase-3. FEBS Lett 584(15):3504-3508. doi:10.1016/j.febslet. 2010.07.019

8. Adamczyk A, Czapski GA, Kazmierczak A, Strosznajder JB (2009) Effect of N-methyl-D-aspartate (NMDA) receptor antagonists on alpha-synuclein-evoked neuronal nitric oxide synthase activation in the rat brain. Pharmacol Rep: PR 61(6):1078-1085

9. Kazmierczak A, Strosznajder JB, Adamczyk A (2008) Alphasynuclein enhances secretion and toxicity of amyloid beta peptides in PC12 cells. Neurochem Int 53(6-8):263-269. doi:10.1016/j. neuint.2008.08.004

10. Adamczyk A, Strosznajder JB (2006) Alpha-synuclein potentiates $\mathrm{Ca} 2+$ influx through voltage-dependent $\mathrm{Ca} 2+$ channels. Neuroreport 17(18):1883-1886. doi:10.1097/WNR. 0b013e3280115185

11. Adamczyk A, Kazmierczak A, Strosznajder JB (2006) Alphasynuclein and its neurotoxic fragment inhibit dopamine uptake into rat striatal synaptosomes. Relationship to nitric oxide. Neurochem Int 49(4):407-412. doi:10.1016/j.neuint.2006.01.025 
12. Jiang T, Hoekstra J, Heng X, Kang W, Ding J, Liu J, Chen S, Zhang J (2015) P2X7 receptor is critical in $\alpha$-synucleinmediated microglial NADPH oxidase activation. Neurobiol Aging 36(7):2304-2318. doi:10.1016/j.neurobiolaging.2015.03. 015

13. Puchalowicz K, Tarnowski M, Baranowska-Bosiacka I, Chlubek D, Dziedziejko V (2014) P2X and P2Y receptors-role in the pathophysiology of the nervous system. Int J Mol Sci 15(12):2367223704. doi:10.3390/ijms 151223672

14. Rodrigues RJ, Tomé AR, Cunha RA (2015) ATP as a multi-target danger signal in the brain. Front Neurosci 9:148. doi:10.3389/ fnins. 2015.00148

15. Gourine AV, Dale N, Llaudet E, Poputnikov DM, Spyer MK, Gourine VN (2007) Release of ATP in the central nervous system during systemic inflammation: real-time measurement in the hypothalamus of conscious rabbits. J Physiol 585(Pt 1):305-316. doi:10.1113/jphysiol.2007.143933

16. Chekeni FB, Elliott MR, Sandilos JK, Walk SF, Kinchen JM, Lazarowski ER, Armstrong AJ, Penuela S, Laird DW, Salvesen GS, Isakson BE, Bayliss DA, Ravichandran KS (2010) Pannexin 1 channels mediate 'find-me' signal release and membrane permeability during apoptosis. Nature 467(7317):863-867. doi:10.1038/ nature09413

17. Bao L, Locovei S, Dahl G (2004) Pannexin membrane channels are mechanosensitive conduits for ATP. FEBS Lett 572(1-3):6568. doi:10.1016/j.febslet.2004.07.009

18. Bargiotas P, Krenz A, Hormuzdi SG, Ridder DA, Herb A, Barakat W, Penuela S, von Engelhardt J, Monyer H, Schwaninger M (2011) Pannexins in ischemia-induced neurodegeneration. Proc Natl Acad Sci U S A 108(51):20772-20777. doi:10.1073/pnas. 1018262108

19. Ho T, Jobling AI, Greferath U, Chuang T, Ramesh A, Fletcher EL, Vessey KA (2015) Vesicular expression and release of ATP from dopaminergic neurons of the mouse retina and midbrain. Front Cellular Neurosci 9:389. doi:10.3389/fncel.2015.00389

20. Kulesskaya N, Võikar V, Peltola M, Yegutkin GG, Salmi M, Jalkanen S, Rauvala H (2013) CD73 is a major regulator of adenosinergic signalling in mouse brain. PLoS One 8(6):e66896. doi:10.1371/journal.pone.0066896

21. Zimmermann H, Braun N (1996) Extracellular metabolism of nucleotides in the nervous system. J Autonomic Pharmacol 16(6):397-400

22. Burnstock G, Kennedy C (1985) Is there a basis for distinguishing two types of P2-purinoceptor? Gen Pharmacol 16(5):433-440

23. Ralevic V, Burnstock G (1998) Receptors for purines and pyrimidines. Pharmacol Rev 50(3):413-492

24. Abbracchio MP, Burnstock G (1998) Purinergic signalling: pathophysiological roles. Jpn J Pharmacol 78(2):113-145

25. Mishra SK, Braun N, Shukla V, Fullgrabe M, Schomerus C, Korf HW, Gachet C, Ikehara Y, Sevigny J, Robson SC, Zimmermann H (2006) Extracellular nucleotide signaling in adult neural stem cells: synergism with growth factor-mediated cellular proliferation. Development (Cambridge, England) 133(4):675-684. doi: $10.1242 /$ dev.02233

26. Burnstock G (2016) An introduction to the roles of purinergic signalling in neurodegeneration, neuroprotection and neuroregeneration. Neuropharmacology 104:4-17. doi:10.1016/ j.neuropharm.2015.05.031

27. Parvathenani LK, Tertyshnikova S, Greco CR, Roberts SB, Robertson B, Posmantur R (2003) P2X7 mediates superoxide production in primary microglia and is up-regulated in a transgenic mouse model of Alzheimer's disease. J Biol Chem 278(15): 13309-13317. doi:10.1074/jbc.M209478200

28. McLarnon JG, Ryu JK, Walker DG, Choi HB (2006) Upregulated expression of purinergic $\mathrm{P} 2 \mathrm{X}(7)$ receptor in Alzheimer disease and amyloid-beta peptide-treated microglia and in peptide-injected rat hippocampus. J Neuropathol Exp Neurol 65(11):1090-1097. doi: 10.1097/01.jnen.0000240470.97295.d3

29. Lee HG, Won SM, Gwag BJ, Lee YB (2011) Microglial P2X(7) receptor expression is accompanied by neuronal damage in the cerebral cortex of the APPswe/PS1dE9 mouse model of Alzheimer's disease. Exp Mol Med 43(1):7-14. doi:10.3858/ emm.2011.43.1.001

30. Abbracchio MP, Ceruti S (2006) Roles of P2 receptors in glial cells: focus on astrocytes. Purinergic Signalling 2(4):595-604. doi:10.1007/s11302-006-9016-0

31. Haynes SE, Hollopeter G, Yang G, Kurpius D, Dailey ME, Gan WB, Julius D (2006) The P2Y12 receptor regulates microglial activation by extracellular nucleotides. Nat Neurosci 9(12): 1512-1519. doi:10.1038/nn1805

32. Domercq M, Vázquez-Villoldo N, Matute C (2013) Neurotransmitter signaling in the pathophysiology of microglia. Front Cell Neurosci 7:49. doi:10.3389/fncel.2013.00049

33. Nishida K, Nakatani T, Ohishi A, Okuda H, Higashi Y, Matsuo T, Fujimoto S, Nagasawa K (2012) Mitochondrial dysfunction is involved in P2X7 receptor-mediated neuronal cell death. J Neurochem 122(6):1118-1128. doi:10.1111/j.1471-4159.2012. 07868.x

34. Jun DJ, Kim J, Jung SY, Song R, Noh JH, Park YS, Ryu SH, Kim JH, Kong YY, Chung JM, Kim KT (2007) Extracellular ATP mediates necrotic cell swelling in SN4741 dopaminergic neurons through P2X7 receptors. J Biol Chem 282(52):37350-37358. doi: 10.1074/jbc.M707915200

35. Strosznajder J, Samochocki M (1992) Carbachol-stimulated release of arachidonic acid and eicosanoids from brain cortex synaptoneurosome lipids of adult and aged rats. Adv Exp Med Biol 318:251-258

36. Wilkaniec A, Schmitt K, Grimm A, Strosznajder JB, Eckert A (2016) Alzheimer's amyloid- $\beta$ peptide disturbs P2X7 receptormediated circadian oscillations of intracellular calcium. Folia Neuropathol 54(4):360-368. doi:10.5114/fn.2016.64813

37. James LR, Andrews S, Walker S, de Sousa PRS, Ray A, Russell NA, Bellamy TC (2011) High-throughput analysis of calcium signalling kinetics in astrocytes stimulated with different neurotransmitters. PLoS One 6(10):e26889. doi:10.1371/journal.pone. 0026889

38. Zieminska E, Stafiej A, Toczylowska B, Albrecht J, Lazarewicz JW (2015) Role of ryanodine and NMDA receptors in tetrabromobisphenol A-induced calcium imbalance and cytotoxicity in primary cultures of rat cerebellar granule cells. Neurotox Res 28(3):195-208. doi:10.1007/s12640-015-9546-8

39. Amoroso F, Capece M, Rotondo A, Cangelosi D, Ferracin M, Franceschini A, Raffaghello L, Pistoia V, Varesio L, Adinolfi E (2015) The P2X7 receptor is a key modulator of the $\mathrm{PI} 3 \mathrm{~K} / \mathrm{GSK} 3 \mathrm{beta} / \mathrm{VEGF}$ signaling network: evidence in experimental neuroblastoma. Oncogene 34(41):5240-5251. doi:10. 1038/onc.2014.444

40. Khan S, Yan-Do R, Duong E, Wu X, Bautista A, Cheley S, MacDonald PE, Braun M (2014) Autocrine activation of P2Y1 receptors couples $\mathrm{Ca}(2+)$ influx to $\mathrm{Ca}(2+)$ release in human pancreatic beta cells. Diabetologia 57(12):2535-2545. doi:10. 1007/s00125-014-3368-8

41. Karczewska J, Piwkowska A, Rogacka D, Stepinski J, Angielski S, Jankowski M (2011) Purinergic modulation of glucose uptake into cultured rat podocytes: effect of diabetic milieu. Biochem Biophys Res Commun 404(2):723-727. doi:10.1016/j.bbrc. 2010.12.051

42. Douillet CD, Suy S, Zarzaur BL, Robinson WP 3rd, Milano PM, Boucher RC, Rich PB (2005) Measurement of free and bound fractions of extracellular ATP in biological solutions using bioluminescence. Luminescence: the journal of biological and chemical luminescence 20(6):435-441. doi:10.1002/bio.869 
43. Kovalevich J, Langford D (2013) Considerations for the use of SH-SY5Y neuroblastoma cells in neurobiology. Methods in molecular biology (Clifton, NJ) 1078:9-21. doi:10.1007/978-162703-640-5 2

44. Cavaliere F, Nestola V, Amadio S, D'Ambrosi N, Angelini DF, Sancesario G, Bernardi G, Volonte C (2005) The metabotropic $\mathrm{P} 2 \mathrm{Y} 4$ receptor participates in the commitment to differentiation and cell death of human neuroblastoma SH-SY5Y cells. Neurobiol Dis 18(1):100-109. doi:10.1016/j.nbd.2004.09.001

45. Khakh BS, Bao XR, Labarca C, Lester HA (1999) Neuronal P2X transmitter-gated cation channels change their ion selectivity in seconds. Nat Neurosci 2(4):322-330. doi:10.1038/7233

46. Virginio C, MacKenzie A, Rassendren FA, North RA, Surprenant A (1999) Pore dilation of neuronal P2X receptor channels. Nat Neurosci 2(4):315-321. doi:10.1038/7225

47. Varma R, Chai Y, Troncoso J, Gu J, Xing H, Stojilkovic S, Mattson MP, Haughey NJ (2009) Amyloid- $\beta$ induces a caspase-mediated cleavage of P2X4 to promote purinotoxicity. NeuroMolecular Med 11(2):63-75. doi:10.1007/s12017-009-8073-2

48. Lohman AW, Leskov IL, Butcher JT, Johnstone SR, Stokes TA, Begandt D, DeLalio LJ, Best AK, Penuela S, Leitinger N, Ravichandran KS, Stokes KY, Isakson BE (2015) Pannexin 1 channels regulate leukocyte emigration through the venous endothelium during acute inflammation. Nat Commun 6:7965. doi:10. 1038/ncomms 8965

49. Vadakkan KI (2016) Neurodegenerative disorders share common features of "loss of function" states of a proposed mechanism of nervous system functions. Biomedicine \& pharmacotherapy $=$ Biomedecine \& pharmacotherapie 83:412-430. doi:10.1016/j. biopha.2016.06.042

50. Soto C (2003) Unfolding the role of protein misfolding in neurodegenerative diseases. Nat Rev Neurosci 4(1):49-60

51. Wilkaniec A, Czapski GA, Adamczyk A (2016) Cdk5 at crossroads of protein oligomerization in neurodegenerative diseases: facts and hypotheses. J Neurochem 136(2):222-233. doi:10. 1111/jnc. 13365

52. Burnstock G (2015) Purinergic signalling in neuroregeneration. Neural Regen Res 10(12):1919-1919. doi:10.4103/1673-5374. 165300

53. Dale N, Frenguelli BG (2009) Release of adenosine and ATP during ischemia and epilepsy. Curr Neuropharmacol 7(3):160 179. doi:10.2174/157015909789152146

54. Carta S, Penco F, Lavieri R, Martini A, Dinarello CA, Gattorno M, Rubartelli A (2015) Cell stress increases ATP release in NLRP3 inflammasome-mediated autoinflammatory diseases, resulting in cytokine imbalance. Proc Natl Acad Sci U S A 112(9):2835-2840. doi:10.1073/pnas.1424741112

55. Massicot F, Hache G, David L, Chen D, Leuxe C, GarnierLegrand L, Rat P, Laprévote O, Coudoré F (2013) P2X7 cell death receptor activation and mitochondrial impairment in oxaliplatininduced apoptosis and neuronal injury: cellular mechanisms and in vivo approach. PLoS One 8(6):e66830. doi:10.1371/journal. pone. 0066830

56. Lin Y, Desbois A, Jiang S, Hou ST (2005) P2 receptor antagonist PPADS confers neuroprotection against glutamate/NMDA toxicity. Neurosci Lett 377(2):97-100. doi:10.1016/j.neulet.2004.11.075

57. Cavaliere F, Sancesario G, Bernardi G, Volonté C (2002) Extracellular ATP and nerve growth factor intensify hypoglycemia-induced cell death in primary neurons: role of P2 and NGFRp75 receptors. J Neurochem 83(5):1129-1138. doi:10. 1046/j.1471-4159.2002.01205.x

58. Cavaliere F, D'Ambrosi N, Ciotti MT, Mancino G, Sancesario G, Bernardi G, Volonte C (2001) Glucose deprivation and chemical hypoxia: neuroprotection by $\mathrm{P} 2$ receptor antagonists. Neurochem Int 38(3):189-197
59. Miras-Portugal MT, Diaz-Hernandez JI, Gomez-Villafuertes R, Diaz-Hernandez M, Artalejo AR, Gualix J (2015) Role of P2X7 and P2Y2 receptors on alpha-secretase-dependent APP processing: control of amyloid plaques formation "in vivo" by P2X7 receptor. Comput Struct Biotechnol J 13:176-181. doi:10.1016/j. csbj.2015.02.005

60. Gan M, Moussaud S, Jiang P, McLean PJ (2015) Extracellular ATP induces intracellular alpha-synuclein accumulation via $\mathrm{P} 2 \mathrm{X} 1$ receptor-mediated lysosomal dysfunction. Neurobiol Aging 36(2):1209-1220. doi:10.1016/j. neurobiolaging.2014.10.037

61. Melani A, Turchi D, Vannucchi MG, Cipriani S, Gianfriddo M, Pedata F (2005) ATP extracellular concentrations are increased in the rat striatum during in vivo ischemia. Neurochem Int 47(6): 442-448. doi:10.1016/j.neuint.2005.05.014

62. Arbeloa J, Pérez-Samartín A, Gottlieb M, Matute C (2012) P2X7 receptor blockade prevents ATP excitotoxicity in neurons and reduces brain damage after ischemia. Neurobiol Dis 45(3):954-961. doi:10.1016/j.nbd.2011.12.014

63. Kimbler DE, Shields J, Yanasak N, Vender JR, Dhandapani KM (2012) Activation of P2X7 promotes cerebral edema and neurological injury after traumatic brain injury in mice. PLoS One 7(7): e41229. doi:10.1371/journal.pone.0041229

64. Peng W, Cotrina ML, Han X, Yu H, Bekar L, Blum L, Takano T, Tian G-F, Goldman SA, Nedergaard M (2009) Systemic administration of an antagonist of the ATP-sensitive receptor P2X7 improves recovery after spinal cord injury. Proc Natl Academy Sci 106(30):12489-12493. doi:10.1073/pnas.0902531106

65. Engel T, Gomez-Villafuertes R, Tanaka K, Mesuret G, SanzRodriguez A, Garcia-Huerta P, Miras-Portugal MT, Henshall DC, Diaz-Hernandez M (2012) Seizure suppression and neuroprotection by targeting the purinergic $\mathrm{P} 2 \mathrm{X} 7$ receptor during status epilepticus in mice. FASEB J 26(4):1616-1628. doi:10.1096/fj. 11-196089

66. Diaz-Hernandez JI, Gomez-Villafuertes R, León-Otegui M, Hontecillas-Prieto L, del Puerto A, Trejo JL, Lucas JJ, Garrido JJ, Gualix J, Miras-Portugal MT, Diaz-Hernandez M (2012) In vivo P2X7 inhibition reduces amyloid plaques in Alzheimer's disease through GSK3 $\beta$ and secretases. Neurobiol Aging 33(8): 1816-1828. doi:10.1016/j.neurobiolaging.2011.09.040

67. Carmo MRS, Menezes APF, Nunes ACL, Pliássova A, Rolo AP, Palmeira CM, Cunha RA, Canas PM, Andrade GM (2014) The P2X7 receptor antagonist Brilliant Blue G attenuates contralateral rotations in a rat model of parkinsonism through a combined control of synaptotoxicity, neurotoxicity and gliosis. Neuropharmacology 81:142-152. doi:10.1016/j.neuropharm. 2014.01.045

68. Iwamaru Y, Takenouchi T, Murayama Y, Okada H, Imamura M, Shimizu Y, Hashimoto M, Mohri S, Yokoyama T, Kitani H (2012) Anti-prion activity of brilliant blue G. PLoS One 7(5):e37896. doi: 10.1371/journal.pone.0037896

69. Díaz-Hernández M, Díez-Zaera M, Sánchez-Nogueiro J, GómezVillafuertes R, Canals JM, Alberch J, Miras-Portugal MT, Lucas JJ (2009) Altered P2X7-receptor level and function in mouse models of Huntington's disease and therapeutic efficacy of antagonist administration. FASEB J 23(6):1893-1906. doi:10.1096/fj. 08-122275

70. Cavaliere F, Dinkel K, Reymann K (2005) Microglia response and $\mathrm{P} 2$ receptor participation in oxygen/glucose deprivation-induced cortical damage. Neuroscience 136(3):615-623. doi:10.1016/j. neuroscience.2005.04.038

71. Melani A, Amadio S, Gianfriddo M, Vannucchi MG, Volontè C, Bernardi G, Pedata F, Sancesario G (2006) P2X7 receptor modulation on microglial cells and reduction of brain infarct caused by middle cerebral artery occlusion in rat. J Cereb Blood Flow Metab 26(7):974-982. doi:10.1038/sj.jcbfm.9600250 
72. Skaper SD, Facci L, Culbert AA, Evans NA, Chessell I, Davis JB, Richardson JC (2006) P2X7 receptors on microglial cells mediate injury to cortical neurons in vitro. Glia 54(3):234-242. doi:10. 1002/glia.20379

73. Choi HB, Ryu JK, Kim SU, McLarnon JG (2007) Modulation of the purinergic $\mathrm{P} 2 \mathrm{X} 7$ receptor attenuates lipopolysaccharidemediated microglial activation and neuronal damage in inflamed brain. J Neurosci 27(18):4957-4968. doi:10.1523/jneurosci.541706.2007

74. Matute C, Torre I, Pérez-Cerdá F, Pérez-Samartín A, Alberdi E, Etxebarria E, Arranz AM, Ravid R, Rodríguez-Antigüedad A, Sánchez-Gómez M, Domercq M (2007) P2X7 receptor blockade prevents ATP excitotoxicity in oligodendrocytes and ameliorates experimental autoimmune encephalomyelitis. J Neurosci 27(35): 9525-9533. doi:10.1523/jneurosci.0579-07.2007

75. Gandelman M, Peluffo H, Beckman JS, Cassina P, Barbeito L (2010) Extracellular ATP and the P2X7 receptor in astrocytemediated motor neuron death: implications for amyotrophic lateral sclerosis. J Neuroinflammation 7(1):33. doi:10.1186/1742-20947-33

76. Kim SY, Moon JH, Lee HG, Kim SU, Lee YB (2007) ATP released from beta-amyloid-stimulated microglia induces reactive oxygen species production in an autocrine fashion. Exp Mol Med 39(6):820-827. doi:10.1038/emm.2007.89

77. Sanz JM, Chiozzi P, Ferrari D, Colaianna M, Idzko M, Falzoni S, Fellin R, Trabace L, Di Virgilio F (2009) Activation of microglia by amyloid \{beta\} requires $\mathrm{P} 2 \mathrm{X} 7$ receptor expression. J Immun (Baltimore, Md: 1950) 182(7):4378-4385. doi:10.4049/ jimmunol.0803612

78. North RA (2002) Molecular physiology of P2X receptors. Physiol Rev 82(4):1013-1067. doi:10.1152/physrev.00015.2002

79. Skaper SD, Debetto P, Giusti P (2010) The P2X7 purinergic receptor: from physiology to neurological disorders. FASEB J: Official Publ Federation Am Societies Exp Biol 24(2):337-345. doi:10.1096/fj.09-138883

80. Lutz PL, Kabler S (1997) Release of adenosine and ATP in the brain of the freshwater turtle (Trachemys scripta) during long-term anoxia. Brain Res 769(2):281-286. doi:10.1016/S0006-8993(97) 00719-1

81. Jurányi Z, Sperlágh B, Vizi ES (1999) Involvement of P2 purinoceptors and the nitric oxide pathway in $[3 \mathrm{H}]$ purine outflow evoked by short-term hypoxia and hypoglycemia in rat hippocampal slices. Brain Res 823(1-2):183-190. doi:10.1016/S00068993(99)01169-5

82. Davalos D, Grutzendler J, Yang G, Kim JV, Zuo Y, Jung S, Littman DR, Dustin ML, Gan W-B (2005) ATP mediates rapid microglial response to local brain injury in vivo. Nat Neurosci 8(6):752-758 doi:http://www.nature.com/neuro/journal/v8/n6/ suppinfo/nn1472_S1.html

83. Gourine AV, Llaudet E, Dale N, Spyer KM (2005) Release of ATP in the ventral medulla during hypoxia in rats: role in hypoxic ventilatory response. J Neurosci 25(5):1211-1218. doi:10.1523/ jneurosci.3763-04.2005

84. Ryu JK, Kim J, Choi S-H, Oh YJ, Lee YB, Kim SU, Jin BK (2002) ATP-induced in vivo neurotoxicity in the rat striatum via P2 receptors. Neuroreport 13(13):1611-1615

85. Franke H, Gunther A, Grosche J, Schmidt R, Rossner S, Reinhardt R, Faber-Zuschratter H, Schneider D, Illes P (2004) P2X7 receptor expression after ischemia in the cerebral cortex of rats. J Neuropathol Exp Neurol 63(7):686-99

86. Penuela S, Gehi R, Laird DW (2013) The biochemistry and function of pannexin channels. Biochim Biophys Acta Biomembr 1828(1):15-22. doi:10.1016/j.bbamem.2012.01.017

87. Huang Y, Grinspan JB, Abrams CK, Scherer SS (2007) Pannexin1 is expressed by neurons and glia but does not form functional gap junctions. Glia 55(1):46-56. doi:10.1002/glia.20435
88. Silverman WR, de Rivero Vaccari JP, Locovei S, Qiu F, Carlsson SK, Scemes E, Keane RW, Dahl G (2009) The pannexin 1 channel activates the inflammasome in neurons and astrocytes. J Biol Chem 284(27):18143-18151. doi:10.1074/jbc.M109.004804

89. Pfeiffer ZA, Guerra AN, Hill LM, Gavala ML, Prabhu U, Aga M, Hall DJ, Bertics PJ (2007) Nucleotide receptor signaling in murine macrophages is linked to reactive oxygen species generation. Free Radic Biol Med 42(10):1506-1516. doi:10.1016/j.freeradbiomed. 2007.02.010

90. Mingam R, De Smedt V, Amedee T, Bluthe RM, Kelley KW, Dantzer R, Laye S (2008) In vitro and in vivo evidence for a role of the P2X7 receptor in the release of IL-1 beta in the murine brain. Brain Behav Immun 22(2):234-244. doi:10.1016/j.bbi. 2007.08.007

91. Gulbransen BD, Bashashati M, Hirota SA, Gui X, Roberts JA, MacDonald JA, Muruve DA, McKay DM, Beck PL, Mawe GM, Thompson RJ, Sharkey KA (2012) Activation of neuronal P2X7 receptor-pannexin-1 mediates death of enteric neurons during colitis. Nat Med 18(4):600-604. doi:10.1038/nm.2679

92. Swayne LA, Bennett SAL (2016) Connexins and pannexins in neuronal development and adult neurogenesis. BMC Cell Biol 17(1):S10. doi:10.1186/s12860-016-0089-5

93. Fischer W, Norenberg W, Franke H, Schaefer M, Illes P (2009) Increase of intracellular $\mathrm{Ca} 2+$ by $\mathrm{P} 2 \mathrm{Y}$ but not $\mathrm{P} 2 \mathrm{X}$ receptors in cultured cortical multipolar neurons of the rat. J Comp Neurol 516(5):343-359. doi:10.1002/cne.22079

94. Locovei S, Scemes E, Qiu F, Spray DC, Dahl G (2007) Pannexin1 is part of the pore forming unit of the $\mathrm{P} 2 \mathrm{X}(7)$ receptor death complex. FEBS Lett 581(3):483-488. doi:10.1016/j.febslet.2006.12. 056

95. Iglesias R, Locovei S, Roque A, Alberto AP, Dahl G, Spray DC, Scemes E (2008) P2X(7) receptor-Pannexin1 complex: pharmacology and signaling. Am J Physiol - Cell Physiol 295(3):C752C760. doi:10.1152/ajpcell.00228.2008

96. Qiu F, Dahl G (2009) A permeant regulating its permeation pore: inhibition of pannexin 1 channels by ATP. Am J Physiol Cell Physiol 296(2):C250-C255. doi:10.1152/ajpcell.00433.2008

97. Ferré S, Quiroz C, Woods AS, Cunha R, Popoli P, Ciruela F, Lluis C, Franco R, Azdad K, Schiffmann SN (2008) An update on adenosine a(2A)-dopamine $\mathrm{D}(2)$ receptor interactions. Implications for the function of $\mathrm{G}$ protein-coupled receptors. Curr Pharm Des 14(15):1468-1474

98. Calon F, Dridi M, Hornykiewicz O, Bedard PJ, Rajput AH, Di Paolo T (2004) Increased adenosine A2A receptors in the brain of Parkinson's disease patients with dyskinesias. Brain J Neurol 127(Pt 5):1075-1084. doi:10.1093/brain/awh128

99. Ismayilova N, Crossman A, Verkhratsky A, Brotchie J (2004) Effects of adenosine A1, dopamine D1 and metabotropic glutamate 5 receptors-modulating agents on locomotion of the reserpinised rats. Eur J Pharmacol 497(2):187-195. doi:10.1016/ j.ejphar.2004.06.030

100. Ferreira DG, Batalha VL, Vicente Miranda H, Coelho JE, Gomes R, Gonçalves FQ, Real JI, Rino J, Albino-Teixeira A, Cunha RA, Outeiro TF, Lopes LV (2017) Adenosine A2A receptors modulate $\alpha$-synuclein aggregation and toxicity. Cereb Cortex 27(1):718730. doi: $10.1093 /$ cercor/bhv268

101. Hu Q, Ren X, Liu Y, Li Z, Zhang L, Chen X, He C, Chen JF (2016) Aberrant adenosine A2A receptor signaling contributes to neurodegeneration and cognitive impairments in a mouse model of synucleinopathy. Exp Neurol 283(Pt A):213-223. doi:10.1016/ j.expneurol.2016.05.040

102. Augusto E, Matos M, Sevigny J, El-Tayeb A, Bynoe MS, Muller CE, Cunha RA, Chen JF (2013) Ecto-5'-nucleotidase (CD73)-mediated formation of adenosine is critical for the striatal adenosine A2A receptor functions. J Neurosci: Offic J Soc Neurosci 33(28): 11390-11399. doi:10.1523/jneurosci.5817-12.2013 